\title{
OBSZAR ZAMIESZKIWANIA, STATUS PRAWNY I KIERUNKI AKTYWNOŚCI GOSPODARCZEJ WOŁOCHÓW/VLACHÓW W ŚREDNIOWIECZU I EPOCE WCZESNONOWOŻYTNEJ*
}

\author{
ILONA CZAMAŃSKA
}

\begin{abstract}
Aвstract. The area of residence, legal status and directions of economic activity of the Wallachians/Vlachs in the Middle Ages and the early modern era.

This article is devoted to the scope of Vlach settlement, Vlach law and its functioning, as well as the socio-economic role of the Vlachs in Central European and Balkan areas. The source material at our disposal does not allow us to define any clear direction for the expansion of the Vlachs as an ethnos, especially since it evolved very quickly in some areas, but undoubtedly, when the Vlachs appear in the sources, their presence is possible to be traced from the Chalkidiki Peninsula to the Carpathians. By observing the functioning of the Vlach law, we can observe a similar development in the entire territory where it was applied, including the countries of Western European and Byzantine-Orthodox tradition, or the Ottoman Empire. Also the evolution of this law was similar and occurred at a similar time. We can observe the following stages of this evolution:

1. till $14^{\text {th }}$ century: shaping the social and self-government system of Vlach communities

2. $14^{\text {th }}-16^{\text {th }}$ centuries: settlement processes and intensive colonization under the Vlach law

3. $16^{\text {th }}-18^{\text {th }}$ centuries: taking up agricultural activities by some Vlachs and their loss of the Vlach law

4. $15^{\text {th }}-18^{\text {th }}$ centuries: using the principles of Vlach law to build the legal status of Military Borderlands

$5.14^{\text {th }}-18^{\text {th }}$ centuries: accession of knez, voivodes and primićurs to the nobility or the timariot class

Vlachs, despite their seemingly primitive way of life and management, played an important civilizational role, enabling the economic use of hard-to-reach and dangerous areas.
\end{abstract}

STRESZCZENIE. Niniejszy artykuł poświęcony będzie kwestii zasięgu osadnictwa wołoskiego, prawa wołoskiego i jego funkcjonowania oraz społeczno-gospodarczej roli środkowoeuropejskich i bałkańskich Vlachów. Materiał źródłowy, jakim dysponujemy, nie pozwala nam wytyczyć jakiegoś wyraźnego kierunku ekspansji Wołochów jako etnosu, zwłaszcza że na niektórych terenach ewoluował on bardzo szybko, niewątpliwie jednak w momencie, gdy w źródłach się pojawiają, widoczni są od Półwyspu Chalkidiki po Karpaty.

Obserwując funkcjonowanie prawa wołoskiego możemy zaobserwować podobny jego rozwój na całym terenie, na którym było ono stosowane, niezależnie od tego, czy były to państwa o tradycji zachodnioeuropejskiej, bizantyńsko-prawosławnej, czy Imperium Osmańskie. Także ewolucja tego prawa przebiegała podobnie i w podobnym czasie. Możemy zaobserwować następujące etapy tej ewolucji:

1. do XIV wieku kształtowanie się systemu społecznego i samorządowego wspólnot wołoskich

2. wiek XIV-XVI: procesy osadnicze i intensywna kolonizacja na prawie wołoskim

3. wiek XVI-XVIII: podejmowanie przez część Vlachów zajęć rolniczych i utrata przez nich prawa wołoskiego 4. wiek XV-XVIII: wykorzystanie zasad prawa wołoskiego do budowy statusu prawnego Pograniczy Wojskowych

5. wiek XIV-XVIII: przechodzenie knezów, wojewodów i primićurów do stanu szlacheckiego lub warstwy timariotów.

Wołosi, mimo pozornie prymitywnego sposobu życia i gospodarowania odegrali ważną rolę cywilizacyjną, umożliwiając wykorzystanie gospodarcze trudno dostępnych i niebezpiecznych terenów.

Keywords: Wallachians/Vlachs, Vlach settlement, Vlach law, Vlach economy

* Artykuł powstał w ramach projektu NPRH Wolosi w europejskiej i polskiej przestrzeni kulturowej. Migracje - osadnictwo - dziedzictwo kulturowe (Projekt nr 0604/NPRH3/H12/82/2014). 
Słowa kluczowe: Wołosi/Vlasi, osadnictwo wołoskie, prawo wołoskie, gospodarka wołoska

Autorka: Ilona Czamańska, Uniwersytet im. Adama Mickiewicza w Poznaniu, Wydział Historii, ul. Uniwersytetu Poznańskiego 7, 61-614 Poznań, Polska, czaman@amu.edu.pl, ORCID iD: https://orcid.org/0000-00020492-0854

Balcanica Posnaniensia. Acta et studia, XXVIII/1, Poznań 2021, Wydawnictwo Wydziału Historii UAM, pp. 7-34

ISBN 978-83-66355-68-2, ISSN 0239-4278. Polish text with summaries in English and Polish

doi.org/10.14746/bp.2021.28.1

Badania nad Wołochami obejmują wiele aspektów: etniczny, językowy, kulturowy, prawny i społeczno-gospodarczy. Niniejszy artykuł poświęcony będzie kwestii zasięgu osadnictwa wołoskiego, prawa wołoskiego i jego funkcjonowania oraz społecznogospodarczej roli środkowoeuropejskich i bałkańskich Vlachów. Semantyka pojęcia Vlachi wiąże się tu przede wszystkim z aspektem kulturowym i społeczno-prawnym, co nie oznacza eliminacji aspektu etnicznego i językowego. Postaramy się tu wyjaśnić następujące zagadnienia:

1. Rozległość osadnictwa wołoskiego i jego powiązanie z obszarem funkcjonowania prawa wołoskiego

2. Ewolucja wołoskich struktur społecznych

3. Gospodarcza rola Wołochów/Vlachów.

Problem określenia miejsca pochodzenia Wołochów/Vlachów jawi się jako wielce skomplikowany. W sensie historycznym wiąże się on nie tylko $\mathrm{z}$ kwestią pochodzenia ludności określanej jako Vlasi czy Blazi, ale także całym kontekstem społecznym, religijnym, państwowym i językowym, w jakim ta ludność funkcjonowała. Był on też przez okres ostatnich kilku stuleci przedmiotem bardzo emocjonalnych dyskusji między historykami rumuńskimi propagującymi teorię o dako-geckim pochodzeniu Wołochów, a badaczami z innych nacji dostrzegającymi inne możliwości w tej mierze. Ze szczególną krytyką Rumunów spotkała się dziewiętnastowieczna teoria Roberta Röslera, który stwierdził, że Wołosi są produktem zmieszania się wielu elementów etnicznych na terenie południowo-wschodniej Europy powstałym dopiero w XII wieku ${ }^{1}$. W pierwszym przypadku miał on sporo racji, w drugim - nie.

${ }^{1}$ R. Rösler, Romänische Studien. Untersuchungen zur älteren Geschichte Romäniens, Leipzig 1871. Przeciw tej teorii: A. D. Xenopol, Teoria lui Rösler. Studii asupra stăruinţei Românilor în Dacia traiană, Iaşi 1884; idem, Une énigme historique. Les roumains au moyen âge, Paris 1885; Onciul Dimitrie, Teoria lui Rösler. Studii asupra stăruinţei Românilor în Dacia traiană, de A. D. Xenopol. Dare de seamă critică, București 1885; idem, Despre controversata chestiune româna (1887); idem, Românii în Dacia Traiană pînă la întemeierea principatelor (Chestiunea română) (1902); idem, Tradiţia istorică în chestiunea originilor române (1907); idem, Idea latinităţii şi a unităţii naţionale (1919). Wszystko przedruk w: idem, 
Przede wszystkim chodzi o datację, Vlasi pojawili się w źródłach znacznie wcześniej. Jako pierwsze wzmianki o nich, nie nazwanych wprawdzie jeszcze, można uznać przekazy pisarzy bizantyńskich piszących w VI-VII wieku, Teofanesa i Teofilakta z Simokatty, na temat języka łacińskiego jako języka ojczystego mieszkańców gór Hemus (Stara Planina)2. Wprawdzie należy bardzo ostrożnie podchodzić do informacji na temat dotarcia Vlachów na górę Athos jeszcze w VIII wieku ${ }^{3}$, niewątpliwie jednak Vlasi pojawiają się w źródłach w wiekach X-XI od razu na znacznym obszarze, w różnych miejscach Półwyspu Bałkańskiego i na ziemiach węgierskich. W średniowieczu i epoce wczesnonowożytnej, obok oczywiście księstw rumuńskich, odnotowano ich obecność w takich miejscach jak: Tesalia i góry Pindos (Konstanty Porfirogeneta, Katakalon Kekaumenos ${ }^{4}$ ), Macedonia (Georgios Kedrenos - Jan Skylitzes, Miron Costin) ${ }^{5}$, Bułgaria i Macedonia (Anna Komnena ${ }^{6}$, Geoffroy de Villardhuin ${ }^{7}$, Robert de Clari ${ }^{8}$, Niketas Choniates ${ }^{9}$, Georgios Pachymeres ${ }^{10}$ i inni),

Scrieri istorice, red. A. Sacerdoțeanu, t. 1-2, Bucureşti 1968. W ślad za nimi poszła cała historiografia rumuńska XX wieku.

${ }^{2}$ Warto zwrócić uwagę na przekazy piszących w VI-VII wieku Teofanesa i Teofilakta z Simokatty na temat języka łacińskiego jako języka ojczystego mieszkańców gór Hemus (Stara Planina). Omówienie poglądów w tej sprawie: N. Saramandu, „Torna, torna Fratre» et la romanité orientale au VI ${ }^{\text {me }}$ siècle, „Revue des Études Sud-Est Européennes” 2002, t. 40, s. 41-60.

3 Według Powieści historycznej monasteru Kostamonitu z Góry Athos w czasach cesarza Bazylego I (726-780) ruszyli się z obydwu brzegów Dunaju Rinkini, Vlachrinkini i Sagudacii, opanowali Bułgarię i Macedonię aż do góry Athos. Na samej Górze Athos osiedliło się 30 rodzin Vlachrinkinów, gdzie przyjęły one chrześcijaństwo i stały się wiernymi chrześcijanami; T. Bujduveanu, Bujduveanu Tănase, Aromânii şi Muntele Athos, București-Constanţa 2002, s. 17-18; Aromâni, meglenoromâni, istroromâni - aspecte identitare şi culturale, red. Adina Berciu-Drăghicescu, Bucureşti 2012, s. 49-50.

${ }^{4}$ Constantinus Porphyrogenitus, De thematibus et administrando imperio, Bonn 1840, s. 125n; Kekaumenos, [w:] Testimonia Najdawniejszych Dziejów Stowian. Seria Grecka, z. 6. Pisarze wieku XI, tłum. i kom. A. Kotłowska, współpr. A. Brzóstkowska, Warszawa 2013, s. 62-105; J. Ферлуга, Кекавмен, [w:] Византийјски извори за историју народа Југославије, t. 3, Београд 1966, s. 189-217; J. Dudek, Dudek Jarosław, Status Wołochów w jedenastowiecznym Bizancjum (wg „Rad” Kekaumena), „Balcanica Posnaniensia. Acta et studia" 2018, t. 25, s. 197-218.

${ }^{5}$ Georgius Cedrenus, Joannus Skylitzes opere, t. 2, Bonnae 1839, s. 435.

${ }^{6}$ Anna Komnena, Aleksjada, thum. Oktawiusz Jurewicz, Wrocław-Warszawa-Kraków 1967-1971, t. 1, s. 131; t. 2, ks. 8,3, s. 34, ks. 10,3, s. 73-74; Anna Comnena, The Alexiad, thum. Elizabeth A. S. Dawes, Cambridge, Ontario 2000, „Ezeba, this is a Vlach village situated close to Androneia” ks. 5,5, s. 90, ks. 8,3 , s. 141 , ks. 10,3 , s. 170-171.

7 Geoffroy de Villehardouin, Zdobycie Konstantynopola, tłum. i kom. Zdzisław Pentek, Poznań 2003, s. 78n, passim.

${ }^{8}$ Robert de Clari, Zdobycie Konstantynopola, thum. i kom. Zdzisław Pentek, Poznań 1997, s. 61, 95 (wyd. II, Poznań 2017, s. 61-62, 102); G. Stabile, Valacchi e Valacchie nella letteratura francese medievale, Roma 2010, s. 101-124.

${ }^{9}$ Nicetae Choniatae, Historia, ex recensione Immanuelis Bekeri, Bonnae 1835, s. 482n.; przedruk i tłumaczenie bułgarskie: Извори за Българската История, t. 25: Гръики Извори за Българската История, t. 11, М. Войнов, В. Тъпкова-Заимова, Л. Йончев, София 1983, s. 41n.

10 Georgii Pachymmeris, de Michaele et Andronico Paleologis, ex recensione Immanuelis Bekeri, Bonnae 1835; przedruk i thumaczenie bułgarskie: Извори за Българската История, t. 22: Гръики Извори за Българската История, t. 10, М. Войнов, В. Тъпкова-Заимова, Л. Йончев, София 1980, s. 185-186, 209. 
Serbia i Kosowo (dokumenty władców serbskich ${ }^{11}$, deftery osmańskie ${ }^{12}$, świadectwa podróżników ${ }^{13}$ ), Czarnogóra i Albania (dokumenty miejskie, dokumenty Balšiciów, dokumenty handlowe Dubrownika ${ }^{14}$ ), Bośnia i Hercegowina (deftery osmańskie, dokumenty ${ }^{15}$ ), państwo weneckie (dokumenty, świadectwa) ${ }^{16}$, Węgry z Chorwacją (kroniki, dokumenty) ${ }^{17}$, Polska i Ruś (dokumenty) ${ }^{18}$. Nie ma całkowitej pewności odnośnie do bytności Vlachów już w XI wieku na terenie dzisiejszej Słowenii, dokument Krešimira IV, który o tym świadczy, rzekomo z 1071 roku, jest najprawdopodobniej falsyfikatem pochodzącym z XII lub XIII wieku ${ }^{19}$. Nie wyklucza to jednak możliwości zamieszkiwania Vlachów także w tej okolicy jeszcze w jedenastym stuleciu.

Zarówno wspomniane wyżej źródła, jak też baza sporządzona w ramach projektu: Wołosi w europejskiej i polskiej przestrzeni kulturowej. Osadnictwo-migracje-dzie-

11 Nie sposób przytaczać tu całego ogromnego materiału źródłowego. Najstarszy dokument serbski dotyczący Vlachów pochodzi z 1198-1199 roku. Wielki żupan Stefan Nemanja nadał monasterowi Hilandar na górze Athos 170 Vlachów; A. Solovjev, Odbrani spomenici srpskog prava (od XII do kraja XV veka), Beograd 1926, s. 14. Pojedyncze dokumenty dotyczące Vlachów trafiają się niemal we wszystkich zbiorach dokumentów dotyczących średniowiecznych Bałkanów. Zob. też: Б. Храбак, Стари Влах од XV до почетка XIX века, „Новопазарски зборник” 1999, t. 23, s. 55-80 i inne artykuły tegoż autora na łamach tegoż czasopisma.

12 H. Šabanović, Krajište Isa-bega Ishakovića. Zbirni katastralni popis iz 1455 godine, Sarajevo 1964; А. Јаковљевић, Н. Исаиловић, Попис нахије Косово из 1574 године, „Мешовита грађа” („Miscellanea”) 2013, t. 34, s. 25-70; Т. Катић, Д. Амедоски, Караванције нахије Петруш из Левча 1502. године, „Мешовита грађа” 2017, t. 38, s. 7-25; Татјана Катић, Опширни попис призренског саниака из 1571. године, Београд 2010; Oblast Brankovića. Opširni katastarski popis iz 1455 godine, red. H. Hadžibegić, A. Handžić, E. Kovačević, Sarajevo 1972; M. Stojaković, Braničevski tefter. Poimenični popis Pokrajne Braničevo iz 1467. godine, Beograd 1987 i inne.

13 Np. Е. Марков, Путовање по Србији и Црној Гори, Подгорица 2005; А. Ф. Гиљфердинг, Путовање по Херцеговини, Босни и Старој Србији, wyd. 2, Београд 1996 i inne.

${ }^{14}$ Državni Arhiv u Dubrovniku, F. 31, 41/A1-A2 i in.; B. Šekularac, Tragovi Vlaha u Crnoj Gori, Emma Books, Şebeş 2012; Š. Kulišić, O etnogenezi crnogoraca, Titograd 1980.

15 Sumarni popis sandžaka Bosna iz 1468/69 godine, red. Ahmed S. Aličić, Mostar 2008; Poimečni popis sandžaka vilajeta Hercegovina 1477, red. Ahmed S. Aličić, Sarajevo 1985; Dva prva popisa Zvorničkog sandžaka iz 1519 i 1533, „Мешовита грађа” („Miscellanea”) 1986, t. 26; Opširni katastarski popis za oblast Hercegovu iz 1585 godine, tłum. Ahmed S. Aličić, t. 2, Sarajevo 2014; Opširni popis Bosanskog sandžaka 1604 godine, red. A. Kupusović, t. 1-3, Sarajevo 2000 i inne.

16 Na temat źródeł weneckich zob. m.in. D. Caciur, Considerations regarding the Morlachs migrations from Dalmatia to Istria and the Venetian settlement policy during the 16th century, „Balcanica Posnaniensia. Acta et studia” 2015, t. 22, nr 1, s. 57-70.

17 Materiał źródłowy z tego terenu jest również bardzo obszerny. Najstarsze źródła: Anonymi Bellae Regis notarii Historia Hungarica de septem primis ducibus Hungariae, [w:] J. Schwandtner, Scriptores Rerum Hungaricarum, t. 1, Vindobonae 1746, s. 10; Anonymus Bele regis notarius, Gesta Hungarorum, wyd. G. Popa-Lisseanu, Bucureşti 1934, s. 32; Scriptores Rerum Hungaricarum, t. 1, wyd. E. Szentpétery, Budapestini 1937, s. 45. Zob. też: Ş. Gheorghe, Românii, care s-au stîns. Valachii din Carpaţii Nordici şi românii din Ungaria, Cluj-Napoca 2012; Ivan Mužić, Vlasi u starijoj hrvatskoj historiografiji, Split 2010.

18 G. Jawor, Osady prawa wołoskiego i ich mieszkańcy na Rusi Czerwonej w późnym średniowie$c z u$, Lublin 2004.

${ }^{19}$ Codex diplomaticus Regni Croatiae, Dalmatiae et Slavoniae, red. M. Kostrenčić, t. 1, Zagrabiae 1967 , s. 123-124. 
dzictwo kulturowe pozwalają rozlokować Wołochów od co najmniej XI-XII wieku na całym obszarze górskim Bałkanów, środkowych i południowych Karpat. Odnośnie Karpat Północnych i terenów położonych na północ od nich (północne stoki Karpat, Ruś Halicka, Roztocze, a nawet Góry Świętokrzyskie), nie mamy źródeł wcześniejszych niż z wieku XIV, co jednak nie wyklucza możliwości zamieszkiwania tam pasterzy wołoskich także znacznie wcześniej. Najdalej na wschód identyfikuje się często z Wołochami notowany w XII-XIII wieku lud Bolohowlenów, nie ma jednak do końca pewności, co do słuszności tej identyfikacji ${ }^{20}$. Na zachodzie osadnictwo wołoskie ewidentnie kończy się na Morawach, nie obejmując już Sudetów i na terenie dzisiejszej Słowenii nie wkraczając głębiej w stronę Alp.

Niemal wszystkie najstarsze źródła wyróżniają Wołochów na podstawie dwóch cech: używania języka rzymskiego czyli ludowej łaciny oraz pasterskiego trybu życia. Istnienie tych dwóch elementów należałoby uznać za podstawowy wyznacznik przynależności do grupy. W przypadku źródeł średniowiecznych, a nawet nowszych, nie zawsze jesteśmy w stanie stwierdzić, jakim językiem posługiwała się na co dzień określona grupa ludzi, zwłaszcza że zapisy też mogą być mylące tym bardziej, że niezależnie od romańskiego elementu etnicznego już najwcześniejsze źródła wskazują na istnienie w społecznościach wołoskich także innych elementów językowych, w szczególności elementu słowiańskiego, helleńskiego i w mniejszym stopniu węgierskiego. Już informacja na temat Rhinovlachów, czyli symbiozy słowiańskich Rhinów i romańskich Vlachów (zakładając, że to nazwa wyłącznie etniczna), może wskazywać na bardzo wczesną obecność Słowian w pasterskich grupach wołoskich. Katakalon Kekaumenos piszący w XI wieku na temat Vlachów w Tesalii, podał między innymi imiona ich przywódców, brzmiały one Slavota i Berivoj ${ }^{21}$. Niewątpliwie więc były to imiona słowiańskie. Jednak Vlasi z tego regionu bardzo szybko ulegli zewnętrznej hellenizacji i nie tylko dziś, ale i dawniej byli identyfikowani z Grekami. Nie przeszkadzało im to jednak we własnym środowisku zachować romańskiego języka określanego jako vlaški i własnych obyczajów.

Źródła z początków wieku XIII konsekwentnie określają mianem Vlachów twórców drugiego państwa bułgarskiego. Jest wielce prawdopodobne, że bracia Iwan Asen, Teodor - Piotr i Kałojan wywodzili się z elity wołoskiej z terenów Starej Płaniny, zapewne jednak posługiwali się głównie, albo również językiem słowiańskim. Niketas

20 Identyfikacja opiera się wyłącznie na podobieństwie nazw: Bolohoveni - Blazi - Vlasi. Ich siedziby znajdowały się na wschód od Dniepru (V. Spinei, Realităţii etnice şi politice în Moldova meridională în secolele X-XIII. Români şi turanici, Iaşi 1985, s. 89 - tam odsyłacze do źródeł i literatury), czyli na terenach nizinnych, mocno odległych od gór, co nietypowe dla Wołochów w tym czasie. Argumenty Vlada Ghimpu na temat romańskiego elementu językowego na Rusi (V. D. Ghimpu, Izvoare medievale româneşti din Rusia şi Finlanda, Chişineu 2012) są mało przekonywające, ale nawet gdyby przyjąć obecność w większym lub mniejszym stopniu zromanizowanych enklaw na terenie wschodniej Rusi, to nie musi oznaczać, że były one wołoskie.

21 Kekaumenos, [w:] Testimonia Najdawniejszych Dziejów Stowian, s. 88-89, 96-97; J. Ферлуга, Кекавмен, s. 214. 
Choniates uważał imię Iwan za vlaską wersję imienia $\operatorname{Jan}^{22}$. Drugie państwo bułgarskie, określane w początkach XIII wieku jako państwo Bułgarów, Wołochów i Kumanów, musiało akceptować odrębność językową i społeczno-organizacyjną tych trzech elementów etnicznych, w miarę upływu czasu ewoluowało ono jednak w kierunku dominującego elementu słowiańskiego. Natomiast na ziemiach na północ od Dunaju, należących jeszcze w 1 połowie XIII wieku do Bułgarii, a później do Węgier, wykształciło się w końcu tego stulecia księstwo Wołoszczyzny, w którym romańskojęzyczni Wołosi zdominowali mieszkającą tam ludność. Podobnie wyglądała sytuacja w sąsiedniej Mołdawii, której ziemie znajdowały się wcześniej, przynajmniej w części, w ramach Rusi Halickiej, Węgier i Złotej Ordy. Mimo to słowiański komponent, obok romańskiego, jest wyraźnie widoczny. Ewidentnie słowiańskie imiona nosili założyciele państwa mołdawskiego: Dragoş i Bogdan. Na terenie Rusi Czerwonej i Orawy Wołosi/Vlasi byli w XV-XVI wieku identyfikowani z Rusinami23. Można więc przypuszczać, że Vlasi byli już wówczas całkowicie zeslawizowani, wyznania prawosławnego.

Element słowiański wśród Vlachów w okresie średniowiecznym widoczny jest w całym niemal regionie bałkańskim. W jednym z najstarszych dokumentów dotyczących ludności vlaskiej, zawierającym spis imienny, mianowicie dokumencie wystawionym w 1220 roku przez króla serbskiego Stefana Nemanjicia dla monasteru Žiča, imiona 252 mężczyzn już wówczas były w większości słowiańskie, za vlaskie można by uznać jedynie pojawiające się kilkakrotnie imię Bukor (rum. Bucur - Szczęśliwy). Zapisane tu imię Kuman może wskazywać na przemieszanie etniczne katunów vlaskich nie tylko ze Słowianami, ale także z Kumanami2 ${ }^{24}$.

Przewagę imion słowiańskich wśród Vlachów dostrzegamy również w defterach osmańskich, zwłaszcza z terenów Serbii oraz Bośni i Hercegowiny. Co ciekawe, bardzo często były to imiona wywodzące się ze słowiańskiej tradycji przedchrześcijańskiej, zwłaszcza zawierające cząstkę Rad- (np. Radoslav, Radomir, Radoj i popularne w Rumunii Radu). Najpóźniej do XVII stulecia nastąpiła na tym obszarze niemal całkowita serbizacja językowa i tożsamościowa Vlachów ${ }^{25}$. Termin Vlach

\footnotetext{
22 Nicetae Choniatae, Historia, [w:] Извори за Българската История, t. 25, s. 50.

${ }^{23}$ G. Jawor, Osady prawa wołoskiego, s. 174-176; idem, Wspótistnienie grup etnicznych na Rusi Czerwonej w XV-XVI wieku na przyktadzie stosunku do społeczności wotoskich, "Annales Universitatis Mariae Curie-Sklodowska" 1997/1998, t. 52-53, s. 61-62. Zob. też list Katarzyny Zrinskiej-Thurzó do cesarza Maksymiliana, b. m. i d., przed 9 kwietnia 1576, w którym pisze: „Sunt binae vel ternae possessiones in comitatu Arwensi, ad castrum Arwa de iure et ab antiquo pertinentes, quas Rutheni vel alio nomine Volachii inhabitant"; W. Semkowicz, Materiaty źródłowe do dziejów osadnictwa Górnej Orawy, t. 2, Zakopane 1939, s. 4.

${ }^{24}$ F. Miklosich, Monumenta Serbica spectantia historiam Serbiae, Bosnae, Ragusii, Viennae 1858, s. 11-16; A. Solovjev, Odbrani spomenici srpskog prava, s. 19-20. Zob. też informacje Jana Kantakuzena na temat Kumanów na służbie cesarza bizantyńskiego Andronika II w 1327 roku. Kumanowie ci mieli pochodzić z Dalmacji; И. Кантакузин, [w:] Византийјски извори за историју народа Југославије, t. 6, Београд 1986, s. 319.

${ }^{25}$ Uczestnicy tzw. wielkich wędrówek Serbów z lat 1690 i 1737 z Kosowa, Starego Vlaha i Brda byli głównie vlaskiego pochodzenia o czym świadczy struktura społeczna plemion zaangażowanych w dzia-
} 
nabrał tu znaczenia przede wszystkim społeczno-kulturowego, co więcej na terenie Bośni i Hercegowiny oraz Czarnogóry jest on obecnie jednoznacznie identyfikowany z Serbami ${ }^{26}$. Nie oznacza to jednak istnienia u źródeł tego podstawowego substratu romańskiego i starobałkańskiego, którego ślady są widoczne w nazewnictwie i kulturze.

Na terenie Dalmacji ludność romańskojęzyczna była obecna od czasów starożytnych, niewątpliwie jednak, także w czasach średniowiecznych miały miejsce migracje z wysp adriatyckich, a zapewne też i z Italii. Pasterze stanowili tylko jedną z wielu grup społecznych ludności romańskiej zamieszkującą początkowo w górnych partiach Gór Dynarskich i Velebitu. Ci tzw. Maurovlasi byli rzymskimi katolikami, wykluczyć więc należy czynnik religijny w procesie ich slawizacji, która i w tym wypadku widoczna jest już w XIV i XV stuleciu. Tradycyjnie badacze łączą ten proces ze stopniowym schodzeniem z gór i mieszaniem się z rolniczą ludnością słowiańską $^{27}$. Procesy językowe nie biegły jednak tylko w jedną stronę, romańszczyzna bowiem zasilana była przesiedleńcami z wysp adriatyckich, przede wszystkim w wyspy Krk, którzy w XV wieku kolonizowali Istrię. Z drugiej strony wołoscy mieszkańcy Istrii migrowali na tereny środkowej Dalmacji. W 1 połowie XVI wieku część Vlachów z Istrii przesiedliła się do części Dalmacji wchodzącej w skład Imperium Osmańskiego. Utworzona została tam wówczas nahija Zrmanja Istrija ${ }^{28}$.

Materiał źródłowy, jakim dysponujemy, nie pozwala nam na jednoznaczne stwierdzenie, kim byli Wołosi w sensie etnicznym u swego zarania i gdzie znajdowała się ich praojczyzna, nie da się wytyczyć jakiegoś wyraźnego kierunku ich ekspansji jako etnosu, zwłaszcza że na niektórych terenach ewoluował on bardzo szybko. Niewątpliwie jednak w momencie, gdy w źródłach się pojawiają, od Półwyspu Chalkidiki po Karpaty, widoczne są wśród nich komponenty romański, starobałkański i po trosze słowiański, które uznać można za charakterystyczne dla wszystkich grup oraz komponenty lokalne (greckie, węgierskie, albańskie, silniejsze słowiańskie) zależne od miejsca zamieszkania.

\footnotetext{
łania wojenne. Zdecydowana większość tych plemion była prawosławna i serbskojęzyczna. Serbska Cerkiew Prawosławna skutecznie serbizowała podległych sobie Vlachów. Szerzej zob. I. Czamańska, Vlachs and Slavs in the Middle Ages and Modern Era, ,Res historica” 2016, t. 41, s. 11-24.

26 Badania terenowe przeprowadzone wiosną 2019 r. na terenie Hercegowiny (okolice Mostaru, Blagaja i Trebinja) oraz Czarnogóry (okolice Žabljaka).

27 S. Pavičić, Starosjedilaštvo današnjeg hrvatskog naselja u Srednjoj i Sjevernoj Dalmaciji. Prilog k proučavanju porijekla Bunjevaca, [w:] I. Mužić, Vlasi u starjoj hrvatskoj historiografiji, Split 2010, s. 74.

28 Opširni popis kliškog sandžaka iz 1550 godine, red. Fehim Dž. Spaho, Ahmed S. Aličić, Sarajevo 2007, s. XI, 8-9.
} 


\section{STRUKTURA SPOŁECZNA WSPÓLNOT WOŁOSKICH}

Struktura społeczna jest elementem, który wyraźnie odróżnia Vlachów od innych społeczności. Na całym obszarze funkcjonowania Vlachów i prawa wołoskiego ewoluowała ona w ciągu wieków w różnych kierunkach, zachowując jednak u podstawy elementy wspólne. Pierwotnie związana była ściśle ze strukturą rodzinną klanem rodowo-plemiennym podporządkowanym naczelnikowi rodu. W okresie historycznym, z którego posiadamy materiał źródłowy, możemy mówić już o bardziej skomplikowanej i wielostopniowej strukturze.

Model struktury społecznej Vlachów grecko-albańskich przedstawił Thede Kahl. Obejmowała ona cztery obszary:

soi - rodziny w szerokim znaczeniu

fălcara - klanu zaangażowanego bezpośrednio w pracach pasterskich

fară - osób nie należących bezpośrednio do klanu, ale w jakiś sposób związanych z grupą

mileti, laou - szerokiego kontekstu, w którym funkcjonowała społeczność Vlachów.

Najważniejszą rolę w społeczności odgrywał czelnik (celnic) - główny organizator wypasu, a zarazem sędzia. Sprawował on władzę nad pasterzami (picurari) i producentami serów (bagi). Pod jego pieczą znajdowały się wielkie stada liczące co najmniej 10000 owiec $^{29}$.

W Rodopach i Macedonii wspólnota pasterska nazywała się sipe i miała charakter czasowy, obowiązywała na czas letniego wypasu. Na jej czele stał wybieralny na sezon kichaja albo czelnik. W okresie zimowym wspólnota ta ulegała rozpadowi. Trwałą wspólnotę stanowiła natomiast wielka rodzina far'. Utrudnienie w badaniu tradycji wołoskich na ziemiach bułgarskich stanowi fakt, że po opanowaniu Bułgarii i Macedonii przez Turków zasiedlano na terytoriach pasterskich dotychczas wykorzystywanych przez Vlachów, małoazjatyckich pasterzy tureckich yuruków. Rezultatem tego były zmiany nazw miejscowych, zmiany statusu prawnego oraz zmiany niektórych obyczajów.

Tylko na terenie Macedonii oraz w Mołdawii niektóre społeczności wołoskie były podzielone na żuzy. Był to system organizacji społeczności typowy dla Azji Centralnej, najprawdopodobniej przyniesiony przez Kumanów, którzy często mieszali się z Wołochami.

Na terenie Serbii, Bośni i Dalmacji czelnik określany był mianem primićur, a podlegające mu rodziny tworzyły wspólnotę zwaną katun. W miarę przechodzenia z pasterstwa w pełni wędrownego do transhumacyjnego primićur pozostał przy obowiązkach pasterskich, natomiast organizacją wsi zajmował się knez. W miarę osiadania we

29 T. Kahl, Le nomadisme chez les Aroumains, [w:] N. Trifon, Les Aroumains un peuple qui s'en va, Acratie 2012, s. 454. 
wsiach zmieniało się znaczenie pojęcia katun, które zaczęto identyfikować ze stałym miejscem pobytu, czasem wsią, a czasem też większą jednostką terytorialną ${ }^{30}$.

Przemiany te wiązały się niewątpliwie ze stopniowym przechodzeniem od pasterstwa w pełni nomadycznego do transhumacyjnego. Był to długotrwały proces trwający kilkaset lat, największe jego nasilenie miało miejsce w XIV-XVI wieku.

Na przykład w połowie XV wieku Vlasi z okolic Sjenicy żyli w 14 katunach pod namiotami. Vlasi z okolic Nikšicia zaczynali w tym czasie prowadzić osiadły żywot ${ }^{31}$. Wsie nahiji Sjenica miały w XVI wieku kneza albo primićura, albo jednego i drugiego. Zachowywały katuńską organizację, nawet jeśli stopniowo przechodziły na uprawę roli ${ }^{32}$. Było to rzadkością. Na ogół bowiem odejście od pasterstwa na rzecz zajęć rolniczych oznaczało utratę specjalnego wołoskiego statusu.

W okresie osmańskim na Bałkanach pojawia się nowe pojęcie dżemat. Było to coś pośredniego między organizacją pasterską, a terytorialno-wojskową. Mógł on skupiać kilka, albo i kilkanaście wsi i szałasów, ale czasami też tylko jedną wieś. Były to przede wszystkim wsie pasterskie, ale zdarzały się również wsie w całości lub w części rolnicze. Na czele dżematu mógł stać kneź bądź wojewoda. Niektóre wsie w ramach ḋ̇ematu mogły mieć dodatkowo jeszcze primićura.

$\mathrm{Na}$ terenie Bałkanów Zachodnich katun uległ przekształceniu w pleme ${ }^{33}$. Odpowiadało to mniej więcej osmańskiemu pojęciu dżemat. Pojawiają się też wówczas naczelnicy plemienni - wojewodowie (vojvoda, vodă), pełniący też, a może przede wszystkim funkcje wojskowe ${ }^{34}$.

Na terenie średniowiecznych Węgier (w Siedmiogrodzie, Maramoreszu, Słowacji) oraz ziem polskich nie mamy śladów źródłowych pełnego nomadyzmu tamtejszych pasterzy wołoskich, co nie wyklucza prawdopodobieństwa jego istnienia.

\section{PRAWO WOŁOSKIE}

Specyfika gospodarki pasterskiej zmuszała z natury do usytuowania Vlachów jako odrębnejkategorii społecznej.Pasterze funkcjonowalinaBałkanachjużw starożytności, niewątpliwie też musieli posiadać odrębny status, jednak nie zachowały się na ten temat żadne konkretne informacje źródłowe. Koczując wysoko w górach żyli własnym

30 Różne znaczenia i różne formy organizacyjne katunów zob. M. Luković, Zakon Vlahom (,,Ius Valachicum") in the charters issued to Serbian medieval monasteries and kanuns regarding Vlachs in the early Ottoman Tax Registers (defters), „Balcanica Posnaniensia. Acta et studia” 2015, t. 22, nr 1, s. $29-46$.

31 Б. Храбак, Стари Влах од XV до почетка XIX века, s. 58.

32 Ibidem, s. 59.

33 M. Luković, Valašske pravo jako základ Valašske kolonizace-komparace z valašským právem na Balkánĕ, [w:] Valašsko historie a kultura, red. Svetava Urbanová, Lumír Dokoupil, Jakub Ivánek, Peter Kadlec, Ostrava 2014, s. 131-137.

${ }^{34} \mathrm{Na}$ przykład we wsiach na terenie Czarnogóry naczelnikiem wsi w czasie pokoju był knez, a w czasie wojny wojewoda. 
życiem i według własnych praw, poza strukturami państwowymi z całym ich aparatem administracyjnym. Nie używali pisma, nie posiadamy więc żadnych zapisów ich języka, a to z kolei nie pozwala stwierdzić do końca jak wyglądał ich skład etniczny. Nie można wykluczyć, że podobnie jak w średniowieczu, były to grupy mieszane etnicznie z przewagą elementu romańskiego lub zromanizowanego. Gdyby potraktować dosłownie występujące w średniowieczu określenie „pastores Romanorum” można by uznać, że stanowili oni w czasach starożytnych zaplecze aprowizacyjne dla rzymskich oddziałów wojskowych ${ }^{35}$. Nie mamy jednak źródeł, które by jednoznacznie potwierdzały takie przypuszczenie.

Z kształtowaniem się prawa wołoskiego w średniowieczu wiązała się autonomia wspólnot pasterskich, w ramach których członkowie wspólnoty podporządkowani byli bezpośrednio własnym wojewodom i kneziom. Na ogół płacili jedynie daninę w postaci 1/50 lub 1/100 części stada, ale zdarzało się też, choć rzadko, że pociągano ich do innych świadczeń. Na Bałkanach Vlasi dzielili się na kalatorów i vojnuków. Kalatorzy byli wyłącznie pasterzami. Vojnucy mieli obowiązek wojskowy, zwłaszcza na terenach pogranicznych, gdzie tworzyli oddziały krajišników, niekiedy obarczano ich tym obowiązkiem również wewnątrz państwa, wykorzystując do pilnowania przepraw i ochrony karawan kupieckich. Po tym, jak właścicielami terenów górskich stały się klasztory lub osoby prywatne zaczęto Vlachów traktować jak ludność zależną. Pilnowano, by poszczególne grupy społeczne nie mieszały się ze sobą, w szczególności zakazane były małżeństwa między Vlachami a ludnością serbską ${ }^{36}$.

W Serbii końca XII wieku Vlasi byli traktowani jak ludność zależna, byli bowiem przedmiotem transakcji handlowych i nadań. W dokumencie z 1198-1199 roku Stefan Nemanja nadał monasterowi Hilandar na górze Athos 170 Vlachów. Vlasi ci mieli wprawdzie pewien samorząd „Radovo sudstvo i Đurđevo”, jednak nie mieli prawa opuszczać terytoriów monasteru ${ }^{37}$.

Stefan Nemanjić uposażając w 1220 r. monaster Žiča, darował mu między innymi 252 Vlachów - mężczyzn wymienionych z imienia. Vlasi ci prowadzili wypas w górach na Spori Nozdri, Javorie z Lukavicami, Gvozd, Želin, a na zimowych pastwiskach od Grieznego Dolu poniżej Sutjeski i po jednej stronie Kotljanika ${ }^{38}$.

Vlachów, którzy znajdowali się we włościach monasterskich można było według prawa św. Symeona i św. Sawy obciążyć pracą w polu: orką i sianokosami na co wskazuje dokument Milutina dla klasztoru św. Jerzego na Seravi pod Skopje z ok. 1300 roku $^{39}$.

Małżeństwa Serbów z Vlahami były zabronione. Według dokumentu nadania króla Serbii Milutina dla klasztoru Banjska z około 1313-1318 roku, jeśli doszło do

35 Anonymi Descriptio Europae Orientalis, red. O. Górka, Cracoviae 1916, s. 13-14.

36 A. V. Solovjev, Odbrani spomenici srpskog prava (od XII do kraja XV veka), Beograd 1926, s. 97.

${ }^{37}$ Ibidem, s. 14.

${ }^{38}$ Ibidem, s. 19-20.

${ }^{39}$ Ibidem, s. 80. 
małżeństwa córki Vlaha z Serbem, miała ona siłą zostać z powrotem doprowadzona do domu ojca, a ojciec i mąż ukarani utratą majątku ${ }^{40}$. W dokumencie wymieniono katuny vlaskie: katun Piajnic (52 mężczyzn), Šišatovc (100), Blgarski (39), Barialevski (64), wieś (?) Proilovcy (co najmniej 12), katun Ursulovc (47), Boboievc (38), Smudirog (108), Voisilc (56+).

Sformułowano tam również prawo dla Vlachów:

1. Od każdych 50 owiec mają oddawać każdego roku 1 owcę z jagnięciem i 1 jałówkę.

2. Jeśli z powodu grzechu zginą cerkwi kobyły oddadzą pierwszego roku co piątą kobyłę.

3. Raz na rok każdy człowiek oddaje cerkwi 2 jagnięta

4. Kto ma sioła, niech kosi siano 3 dni i donosi rocznie towar [miara objętości] zboża, a inny wino.

5. I niech donoszą soli cerkiewnej, odkąd im igumen powie od 40 klatiszcz [kolib pasterskich] 10 towar

6. Kto jest wojnikiem i nie ma obciążeń wobec cerkwi ten daje od siebie okroje [rodzaj obuwia]

7. Wojnik i kelator niosą ser z gór

8. Kelator pasie i strzyże wełnę, a wojnik wypasa przez pastuchów

9. A w zły czas i wojnik i kelator niech grodzą owce.

10. I ogrodzenie wspólne dla 6 wołów, a końskie dla 6 koni.

11. A cała ziemia vlaška na Kijevie, a granica Kijeva od Smudiglava na głowę i od głowy na Kruszkę i na Domanegę ${ }^{41}$.

Dokumenty średniowieczne $\mathrm{z}$ terenów Serbii wspominają Vlachów przede wszystkim w związku z uposażeniem klasztorów. Król serbski Milutin darował Vlachów monasterowi Gračanica ${ }^{42}$. W dokumencie - nadaniu dla monasteru Visoki Dečani z ok. 1330 r. Stefan Uroš Dečanski uwolnił podległych klasztorowi Vlachów od obciążeń na rzecz króla. Vlasi mieli m.in. zajmować się zaopatrywaniem klasztoru w sól ${ }^{43}$. W nadaniu Stefana Duszana dla cerkwi św. Bogurodzicy Privlepte w Ochrydzie z 1345 r. znalazło się również seliszcze Frugovi Vlasi ${ }^{44}$.

Nadanie cara Duszana dla klasztoru św. Archaniołów Michała i Gabriela pod Prizrenem z 1348 r. określało dokładnie obowiązki ludności na terytoriach podarowanych monasterowi:

żaden człowiek cerkwi, ani Vlach ani Serb nie ma być powoływany do wojska. I nie wykonują oni żadnych prac na rzecz cara. Cerkiewne owce mają paść Brogianie, a kobyły Vlasi Dobrušincy i im się daje na św. Dymitr 10 perper na 2 źrebaki, kożuchy, gunie i nogawice (pończochy ?) i niech dają dochód od wina jak inni Vlasi. I daje się 12 kożuchów braciom i całą pszenicę, jak się daje w Banjskiej, i serów 24 worki, a każdy worek 120 litrów i serów [twardych] tyleż a ser 6 litrów, 3 kielbie soli, 3 skóry wołowe, po okryciu i pończochach, a na Wielkanoc po 1 perper, a wina tyle ile otrzymują mnisi z monasteru.

\footnotetext{
40 Ibidem, s. 93.

41 Ibidem, s. 97.

42 Dokument darowizny Milutina, 1320-1321: ibidem, s. 102-103.

43 Ibidem, s. 115 .

${ }^{44}$ Ibidem, s. 128.
} 
W ramach tego dokumentu znalazł się Zakon Vlahom, czyli Prawo dla Vlachów:

Niech dają od 50 - owcę z jagnięciem i jałówkę z runem i w roku przestępnym konia wartości 30 perper jak dawali mnie, a teraz carowi nie dają. I niech dają od „klatiszcza” jagnięcinę i wnętrzności. Pokłonnicy niech sami się dziesiątkują i oddają jesienią okrycie [koc, pled], a wiosną 2 owce jałowe. A ubodzy Vlasi niech przędą wełnę cerkiewną ile im każe igumen. A inni Vlasi niech dają okrycia i pończochy, niech noszą sól, a zimą niech koszą siano dla kobył, niech naprawiają gród, grodzą jagnięta, pasą bydło i kobyły, niosą zboże i towar z igumenem ${ }^{45}$.

Na ziemiach chorwackich status Vlachów był różny w zależności od tego, na czyjej ziemi mieszkali. Ogromne znaczenie tamtejszych rodów możnowładczych oznaczało $\mathrm{w}$ praktyce, że każdy $\mathrm{z}$ nich stanowił odrębne prawo dla swych poddanych. $\mathrm{Z}$ drugiej strony, podobnie jak na innych terenach klany wołoskie miały podobne obowiązki i samorząd.

Przykładem prawa Vlachów jest dokument bana Hanža Frangopana z 1436 roku, potwierdzający dokument Ivaniša Ivanovicia wydany dla Vlachów cetinskich. W świetle tego dokumentu Vlasi mieli nad sobą postawionego knezia, którego jednak mieli prawo zmienić, gdyby z jakiegoś powodu okazał się niedobry. Ich obciążenia były relatywnie duże. Zobowiązani byli do płacenia na dzień św. Jerzego owcy albo barana, a także podymnego w pieniądzach. Szczególną rolę w zobowiązaniach Vlachów Cetinskich odgrywał obowiązek wojskowy, za którego realizację odpowiedzialny był wojewoda. Ten ostatni musiał być Vlahem i nie wolno było narzucać nikogo innego. Gdy rekrutowano Vlachów do wojska nie wolno było rekrutować więcej jak 2/3, trzecia część musiała pozostać przy obowiązkach pasterskich. Vlach, który posiadał wieś (czyli knez lub wojewoda) musiał się stawić z pocztem, natomiast zwyczajny Vlah służył na koniu z tarczą i mieczem albo z łukiem i mieczem. Od służby wojskowej można się było jednak wykupić płacąc określoną liczbę pieniędzy, z których 1/10 przypadała wojewodzie. Między dniem św. Stefana (2 września) a św. Marcina (11 listopada) nie wolno było Vlahów zmuszać do udziału w działaniach wojennych, co niewątpliwie wiązało się z koniecznym przepędem stad na pastwiska zimowe. Podobnie jak na innych terenach, tak i cetinscy Vlasi mieli własny samorząd sądowniczy, nad którym czuwał knez, organizując dwa razy do roku posiedzenia sądowe ${ }^{46}$.

Vlasi, mimo swoich praw samorządowych, byli traktowani na zachodnich Bałkanach jako ludność zależna, byli przedmiotem darowizn, odmawiano im też pełnej osobowości prawnej, niekiedy jednak zdarzały się wypadki samodzielnego wystawiania dokumentów przez społeczności vlaskie. Świadectwem może być dokument wystawiony 16 sierpnia 1433 roku w Lice przez wojewodę, kneziów i sędziów vla-

45 Ibidem, s. 135-142, tam s. 142.

${ }^{46}$ R. Lopašić, Cetinski i lički vlasi, w: I. Mužić, Vlasi u starjoj hrvatskoj historiografiji, Split 2010, s. 19-30, tam:28-30, Toż w interpretacji Nady Klaić: ibidem, s. 38-42. 
skich dla kościoła św. Jana na górze w Lice, w którym zobowiązali się oni w imieniu całej tamtejszej społeczności wołoskiej nie naruszać dóbr kościoła ${ }^{47}$.

Na ziemiach węgierskich w XIII wieku Vlasi podlegali tylko królowi i mieli własny samorząd. W dokumencie Béli IV z 1247 roku, nadającym zakonowi joannitów ziemie w okolicach Braszowa i w Banacie Seweryńskim, wymieniono dwa knezaty wołoskie nad rzeką Olt pod wodzą Litwoja i Seneslawa, które zostały wyjęte spod władzy zakonu ${ }^{48}$. Knezaty te interpretuje się raczej mylnie jako księstwa, traktując je jak organizacje zapoczątkowujące państwowość wołoską, gdy tymczasem w całym tym regionie knez oznaczał raczej naczelnika wsi, plemienia lub grupy pasterskiej. Inna rzecz, że na terenach, na których powstały księstwa rumuńskie Wołoszczyzna i Mołdawia, można zaobserwować bardzo szybki rozpad tradycyjnych wspólnot wołoskich i odchodzenie ich od gospodarki pasterskiej, która staje się domeną Cyganów i Tatarów.

W dokumentach hospodarów wołoskich z XIV wieku: Dana I, Mirczy Starego dla monasterów Tismana i Cozia, to miejsce, które w analogicznych dokumentach serbskich zajmują zwykle Vlasi, zajmują Cyganie i to w bardzo znacznej liczbie. Pierwszy znany taki dokument wystawiony został w roku 1385 przez Dana I dla monasteru Tismana, jednak jest w nim również potwierdzenie nadania jego wuja Władysława I dla monasteru św. Antoniego 40 czeladzi cygańskiej ${ }^{49}$. Podobnie w dokumencie Mirczy Starego z 1388 roku dla monasteru Cozia znajduje się nadanie 300 Cyganów $^{50}$. Nie jest jasne czy Cyganie ci zajęli miejsce pasterzy wołoskich, czy też, jak to później było powszechne na Wołoszczyźnie, wykorzystywano ich też do prac polowych oraz różnego innego rodzaju posług ${ }^{51}$. Zachowane dokumenty nie dają nam jasności jak funkcjonowały wsie na Wołoszczyźnie i czy w ogóle stosowano tam system znany jako wołoski. Niewątpliwie były pewne jego elementy, jak instytucja kniazia posiadającego uprawnienia sądownicze ${ }^{52}$. Szybko jednak następowała tu ewolucja kniaziów w kierunku właścicieli ziemskich.

Z drugiej strony dokładniejsza analiza osadnictwa i gospodarki w poszczególnych regionach i wsiach pozwala wyrazić wątpliwość czy rzeczywiście wszystkie osady identyfikowane jako wołoskie istotnie takimi były. Czynnikiem identyfikującym osadnictwo wołoskie w środkowej Europie jest struktura społeczna, obecność kniaziów/knezów w organizacji wsi i wojewodów jako reprezentantów większej zbio-

47 R. Lopašić, Zakon za ličke vlahe od g. 1433, w: I. Mužić, Vlasi u starjoj hrvatskoj historiografiji, s. 33-37. Toż w interpretacji Nady Klaić: ibidem, s. 37-38.

48 Documenta Romaniae Historica, red. Petre P. Panaitescu, Damaschin Mioc, B (Ţara Românească), t. 1 (1247-1500), Bucureşti 1966, s. 3-7.

49 P. P. Panaitescu, Documentele Ţării Româneşti, t. 1 (Documente interne; 1369-1490), Bucureşti 1938, s. 39. W tłumaczeniu rumuńskim mylnie 40 salaszy cygańskich.

50 Ibidem, s. 48.

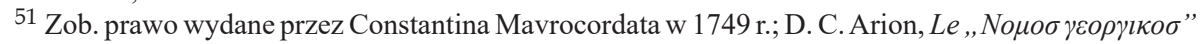
et la régime de la terre dans l'ancien droit roumain jusqu'a la reforme de Constantin Mavrocordat (hospodar de Moldavie et de Valachie (1733-1769), Paris 1929, s. 174-175.

52 V. Costachel, P. P. Panaitescu, A. Cazacu, Viaţa feudală în Ţara Românească şi Moldova (sec. XIV-XVII), Bucureşti 1957, s. 173-176. 
rowości. Tymczasem knezowie stanowili czynnik organizacyjny nie tylko wsi wołoskich, ale również serbskich. Na taką proweniencję zdają się wskazywać wsie, których mieszkańcy nie trudnili się pasterstwem, lecz hodowlą świń, co było specjalnością Serbów. Ponadto liczne tereny, które były obiektem kolonizacji wołoskiej należały w XV i częściowo w XVI wieku do serbskich Brankoviciów. Między innymi ich majętności znajdowały się w komitacie Bereg w rejonie Mukaczeva (Munkacsa), gdzie istniał region kolonizacji wołoskiej. Najprawdopodobniej z osadnictwem serbskim związany jest dokument królowej Marii dla Lazara (notabene imię też może wskazywać na Serba) kneza Kalnika z roku 1520, nadający mu miejscowość Lazarfalva, którą sam założył. Mieszkańcy mieli 40 lat wolnizny, ale na rzecz kneza mieli przekazywać dziesięcinę ze świń ${ }^{53}$. Podobnie rzecz się miała z miejscowością Obava (węg. Dunkófálva) lokowaną krótko przed 1568 r. przez Danka Koczana (dokument potwierdzający lokację 4 lutego 1568 r. wystawiony przez Ludwika, żupana komitatu Bereg). $Z$ dokumentu, poza tym, że wieś miała kneza, zupełnie nie wynika, by mogło to być osadnictwo wołoskie. Ludność trudniła się rolnictwem (knez miał prawo budowy młyna i handlowania mąką w Munkaczu) i hodowlą świń (mieszkańcy mieli obowiązek dostarczania ich do Munkacza), co nie było typowe dla gospodarki wołoskiej. Ponadto w dokumencie nie ma nic na temat obowiązku wojskowego, co również pozwala wątpić w wołoski charakter wsi ${ }^{54}$.

Na terenie państwa węgierskiego Wołosi podlegali swoim knezom, mianowanym przeważnie przez króla, ewentualnie przez właściciela wsi, o ile wieś była prywatna. W praktyce, mimo mianowania, knezostwo było przeważnie dziedziczne, a nawet bywało, że członkowie rodu pełnili je kolegialnie. Przykładem może być knezostwo Ieud (Jood) w Maramoreszu nadane Walentemu, synowi Teodora i jego 5 braciom, a później Teodorowi synowi Walentego i jego licznym krewnym ${ }^{55}$. Oczywiście w grę tu wchodził nie tyle sam urząd, co prawo do korzystania z wynikających z niego profitów, które były niejednokrotnie bardzo znaczne, niektóre siedziby knezowskie nie ustępowały szlacheckim.

Inaczej wojewodowie. Wprawdzie stanowisko wojewody było przeważnie stanowiskiem z wyboru, jednak wybór ten dokonywał się w praktyce spośród przedstawicieli najbogatszej wołoskiej elity posiadającej majątki ziemskie. Nie było to zresztą zjawisko odosobnione, dostrzegamy je również na całych Bałkanach. Król jednak mógł w razie nieposłuszeństwa usunąć wojewodę i odebrać mu majętności, jeśli okazał się nieposłuszny. Tak było z wojewodą Bogdanem ze wsi Kuhnya w Maramoreszu, w rezultacie czego wyemigrował on na niezagospodarowane terytoria Mołdawii, stając się jednym z założycieli księstwa mołdawskiego. Majętność Bogdana została nadana jego wrogom: synom Sasa a wnukom Dragosza, którzy utrzymywali ją przez kolejne pokolenia ${ }^{56}$. Niezależnie od właścicieli, wieś miała jednak również kneziów

\footnotetext{
${ }^{53}$ K. Kadlec, Valaši a valašské právo v zemíh slovanských a uherských, Praha 1916, s. 489-490.

54 Ibidem, s. 490-491.

55 J. Mihályi, Máramarosi diplómak a XIV. és XV századból, Máramaros-Sziget 1900, s. 245-246.

${ }^{56}$ Ibidem, s. 56-58.
} 
pochodzących tradycyjnie z rodu Maris ${ }^{57}$. Wołoscy właściciele wsi od XV wieku nazywali się Dolhai, weszli do warstwy szlacheckiej Węgier i ulegli madziaryzacji (ród przetrwał do dziś). Nobilitacja i madziaryzacja tej grupy Wołochów była zjawiskiem powszechnym i długotrwałym, miała ona miejsce od XIV po XVII stulecie.

Na terenie Siedmiogrodu, podobnie jak na innych terenach, podstawowym obowiązkiem pasterzy wołoskich wobec władcy była danina w postaci części stada i w produktach. W okresie istnienia Księstwa Siedmiogrodzkiego zwyczajowo pobierano od 25 owiec jedną owcę z barankiem na rok, od 50 owiec jedną owcę z rocznym jagnięciem na rok, od 75 owiec dwie owce z barankiem i rocznym jagnięciem na rok, od 100 owiec dwie owce z dwoma barankami i dwoma rocznymi jagniętami na rok. Te daniny w owcach zamieniano później na opłatę w pieniądzach. I tak w 1578 roku do 32 owiec nie pobierano nic, od 50 owiec 99 denarów, a później od każdej owcy lub kozy po jednym denarze ${ }^{58}$. Daniny płacono też od upraw i innych zwierząt.

W tym samym czasie w habsburskiej części Węgier obciążenia były wyższe, w komitatach Turocz (Turiec), Nyitra (Nitra) i Zolyom (Zvolen) obowiązywała dwudziesięcina, czyli jedna owca lub koza od dwudziestu ${ }^{59}$.

Znakomitym przykładem prawa wołoskiego na terenie dzisiejszej Słowacji jest dokument Macieja Korwina z 1474 roku wystawiony dla mieszkańców Orawy i Liptowa. W świetle tego dokumentu Wołosi z tego terenu byli zwolnieni od płacenia wszystkich podatków i od prac na rzecz zamku, podlegali sądownictwu własnego wojewody, lecz mogli od jego wyroku odwołać się do króla. Mogli też swobodnie handlować własnymi towarami bez jakichkolwiek opłat i myt. Byli natomiast zobowiązani do świadczeń w naturze 5 owiec lub kóz od 100 oraz dodatkowo jednej owcy niezależnie od wielkości stada. Szczególną wagę przywiązywano jednak do obowiązku wojskowego, a właściwie służby porządkowej. Wszyscy mężczyźni wołoscy mieli obowiązek posiadania broni, co najmniej łuku lub procy, stałego pilnowania porządku na drogach oraz ochrony karawan kupieckich ${ }^{60}$. Widać tu więc duże podobieństwo do statusu Vlachów bałkańskich, pełniących podobne funkcje.

Do osadnictwa wołoskiego odnosi się dokument Ferdynanda I z 18 stycznia 1550 dla 5 wsi z Orawy: Dubova (Valaská Dubová), Knyesy (Kňažia), Medzybrogy (Medzibrodie nad Oravou), Wsthy (Ústie) i Bziny, których mieszkańcy byli zobowiązani do pełnienia służby porządkowej na rzecz zamku i posiadania w tym celu łuków i kusz ${ }^{61}$.

Najdawniejsze informacje na temat Wołochów i prawa wołoskiego na ziemiach polskich pochodzą z XIV wieku, jednak właściwy rozwój kolonizacji wołoskiej na terenie Bieszczad i Beskidów nastąpił w XV-XVI stuleciu. Z najnowszych badań prowadzonych przez Grzegorza Jawora wynika, że gospodarka pasterska prowadzona

57 Ibidem, s. 332, 373-375.

58 F. Pintescu, Românii din Transilvania la sfârşitul secolului XVI şi începutul secolului XVII, Suceava 2004, s. 69-70.

${ }^{59}$ Ş. Meteş, Emigrării româneşti din Transilvania în secolele XIII-XX, Bucureşti 1977, s. 46.

60 K. Kadlec, Valaši a valašské právo, s. 494-496.

61 Ibidem, s. 497. 
przez Wołochów na terenie Polski nie miała fazy czysto koczowniczej, lecz od początku miała charakter transhumancyjny lub nawet czysto osiadły ${ }^{62}$. W najogólniejszych zasadach prawo wołoskie na obszarze północnych Karpat posiadało te same cechy, co na Bałkanach, czyli samorząd sądowniczy, podatek z części stada oraz obowiązek wojskowy. Praktyczne rozwiązania były jednak dość mocno zróżnicowane, a ogólna ewolucja też biegła w nieco innym kierunku. Wynikało to z faktu, że kolonizacja wołoska rozwijała się tu dość późno, brała w niej udział ludność z różnych terenów, która przynosiła ze sobą własne zwyczaje. Nie sformułowano na ziemiach polsko-litewskich jednolitej zasady prawnej dotyczącej gospodarki pasterskiej, ziemie, na których osiedlali się Wołosi były już bardzo często prywatną własnością, w praktyce więc z każdym właścicielem osobno trzeba było uzgadniać zasady. Były one formułowane w dokumentach lokacyjnych poszczególnych wsi. Przedstawicielem i organizatorem wołoskiej społeczności był kniaź, który pełnił też funkcje sądownicze ${ }^{63}$. Był on więc jednocześnie odpowiednikiem sołtysa i wójta we wsiach na prawie niemieckim. Nie ma jasności czy kniaź był wybierany oddolnie, czy też był dziedziczny. Badania prowadzone przez Grzegorza Jawora w odniesieniu do Rusi Czerwonej wskazują na dziedziczność tej funkcji ${ }^{64}$, wskazują też na to wcześniejsze badania Stanisława Szczotki na Żywiecczyźnie i Śląsku Cieszyńskim5.

Na czele większej społeczności, złożonej z kilku - kilkunastu wsi stał wojewoda, przeważnie mianowany przez właściciela i w odróżnieniu od Bałkanów, nie był dziedziczny. Pełnił on funkcje koordynacyjne i sądownicze jako sędzia apelacyjny, a z biegiem czasu stał się urzędnikiem pilnującym interesów właściciela wsi. Do jego obowiązków należało, między innymi, pilnowanie lasów przed dziką eksploatacją. Wojewodowie wołoscy na ziemiach polskich nie byli ani tak bogaci, ani tak samodzielni jak na Węgrzech czy na Bałkanach w okresie przedosmańskim, niejednokrotnie byli wręcz opłacani przez właściciela gruntu i składali mu przysięgę na wierność 66 .

Wojewoda i kniaź mieli obowiązek osobistej służby wojskowo-policyjnej, natomiast w odniesieniu do pozostałych mężczyzn wyglądało to różnie. Niekiedy żądano od osadników wołoskich zaopatrzenia się i posiadania konkretnych rodzajów broni. W XVI wieku bardzo często obowiązek wojskowy zamieniano na opłatę pienięż-

62 G. Jawor, Osady prawa wołoskiego, s. 47-48. Autor polemizuje tu z rozpowszechnioną tezą Kazimierza Dobrowolskiego o koczowniczych pasterzach wołoskich w Beskidach; K. Dobrowolski, Migracje wołoskie na ziemiach polskich, [w:] Pamiętnik V Powszechnego Zjazdu Historyków Polskich w Warszawie 28 listopada do 4 grudnia 1930 r., Lwów 1930, s. 143.

$63 \mathrm{Na}$ temat instytucji sądowniczych we wsiach wołoskich zob. G. Jawor, Strungi i zbory. Instytucje organizacji społecznej wsi na prawie wołoskim w średniowiecznej Polsce, „Kwartalnik Historii Kultury Materialnej” 1997, t. 45, nr 2, s. 179-186.

64 G. Jawor, Osady prawa wołoskiego, s. 133.

65 S. Szczotka, Studia z dziejów prawa wołoskiego w Polsce, „Czasopismo prawno-historyczne” 1949 , t. 2, s. 364-365.

66 Ibidem, s. 385-390. 
ną ${ }^{67}$. Podatki od pasterzy pobierano przeważnie w naturze 5 owiec lub 5 kóz od 100 , jedynie od osób, które posiadały jakieś grunty rolne i uprawy żądano dodatkowych świadczeń, a i to nie zawsze. Charakterystyczne dla ziem polskich było systematyczne poszerzanie się tego rolniczego marginesu, który z czasem stawał się dominujący. Proces ten wiązał się najczęściej z utratą praw wolnościowych i wejściem w struktury feudalne. W rezultacie niektóre wsie całkowicie traciły swój status. Przykładem tego może być Kobylnica Wołoska na Roztoczu, która na początku XVIII wieku nie posiadała już w ogóle prawa wołoskiego ${ }^{68}$. Inna rzecz, że była to jedna z nielicznych wsi wołoskich, która nie powstała na terenach górskich ${ }^{69}$.

W Imperium Osmańskim sytuacja prawna Vlachów była również zróżnicowana w zależności od obszaru i wcześniejszego statusu. We wsiach, które jako całość posiadały prawo wołoskie, cała ludność podlegała temu prawu niezależnie od tego czym się zajmowała, na ogół jednak wyraźnie rozróżniano pasterzy i rajów, trudniących się rolnictwem. Badania nad prawem wołoskim w dobie osmańskiej komplikuje jednak fakt sprowadzenia na teren Bałkanów małoazjatyckich yuruków, którzy niejednokrotnie w defterach osmańskich, zwłaszcza późniejszych, określani są tym samym mianem, co vlasi - hajmani. Pojawili się też liczni Romowie, również prowadzący żywot koczowniczy. Na szczęście jednak dysponujemy dostatecznie bogatym materiałem źródłowym z różnych obszarów bałkańskich, by móc określić jak prawo wołoskie działało pod panowaniem osmańskim ${ }^{70}$.

Katuny wołoskie, nawet te, które prowadziły wędrowny tryb życia, miały ściśle określone pastwiska letnie i zimowe, a w ciągu XVI wieku praktycznie zamknięty został proces osadniczy, przynajmniej formalnie wszyscy pasterze zostali przypisani do konkretnej wsi, wymagał tego bowiem system podatkowy.

Podstawowym podatkiem płaconym przez pasterzy wołoskich $\mathrm{w}$ państwie osmańskim był podatek ryczałtowy, zwany filurią. Jest to podstawowy element prawny odróżniający pasterzy wołoskich od innych grup pasterskich na terenie Imperium Osmańskiego. Podatek ten pobierany był najpierw od katuna, a później płaciła go każda rodzina wołoska zajmująca się pasterstwem. Miał on charakter stały, niezależny od wielkości posiadanego stada ${ }^{71}$. W zależności od czasu i miejsca filuria mogła wynosić 45, 50, 100 a nawet więcej akczy. Dodatkowo pobierano podatek pasterski wartości 2 baranów z zamianą na pieniądze np. po 15 akczy każdy, i 2 owiec, również z zamia-

${ }^{67}$ K. Kadlec, Valaši a valašské právo, s. 349-350; S. Szczotka, Studia z dziejów prawa wołoskiego w Polsce, s. 368. Jak dowiódł G. Jawor, zwyczaj ten miał swoje początki już w XV wieku; G. Jawor, Osady prawa wołoskiego, s. 73-74.

68 Inwentarze i rozliczenia folwarczne wsi Kobylnicy Ruskiej i Kobylnicy Woloskiej z lat 1711-1723, red. Bogumiła Kowal, Stanisław Baran, Przemyśl 2014, passim.

69 Ostatnio obserwujemy jednak coraz więcej przykładów takich wsi. Zob. T. Figlus, Villae iuris valachici. Z problematyki rozwoju osadnictwa wołoskiego w Polsce na przykladzie ziemi sanockiej, ,, Studia z geografii politycznej i historycznej” 2016, t. 5, s. 11-37.

70 Szerzej o tym I. Czamańska, Wolosi/Vlasi z terenów Hercegowiny w świetle defterów osmańskich z XV i XVI wieku, „Balcanica Posnaniensia. Acta et studia” 2018, t. 25, s. 219-249.

${ }^{71}$ Był to element wyróżniający Vlachów, których nie obowiązywał podatek od dużego stada adet-iagnum. 
ną na pieniądze. Ponadto z każdych 50 domów należało zapłacić taksę wartości 1 namiotu i dodatkowo 2 barany lub ich równowartość.

W defterze z 1477 r. dla wilajetu Hercegowina znalazło się sformułowanie obowiązków dla miejscowych Vlachów:

\begin{abstract}
Na dzień znany pod nazwą Đurđevdan (Hizir Iljas) każdego roku dają z domu po jednej filurii i po jednej owcy z jagnięciem albo ich równowartość 12 akczy, 1 barana albo jego równowartość 15 akczy, dalej dają na każde 50 domów 2 barany albo ich równowartość 60 akczy, także na każde 50 domów 1 namiot albo jego równowartość 100 akczy, ponadto jeśli jest wojna oddają z każdych 10 domów 1 eskendżiję, który idzie na wojnę. Kiedy zostanie spełnione to, co wspomniano, są wolni od wszystkich pozostałych obowiązków ${ }^{72}$.
\end{abstract}

Status Vlachów w państwie osmańskim był bardzo dla nich korzystny, jednak jego utrzymanie, podobnie jak na innych terytoriach, było trudne. Osiedlanie się Vlachów, a przede wszystkim podejmowanie przez część z nich pracy na roli, prowadziło do ich spadku do kategorii rajów.

Prawo wołoskie było w państwie osmańskim było ściśle powiązane z obowiązkiem wojskowym. Najlepiej zorganizowaną jednostką związaną z Vlachami byli vojnucy. Rekrutowano ich ze wsi wołoskich, ale sama procedura była dość skomplikowana. Najpierw na 5 lub 10 domów wybierano jednego eskendżiję. Stał on na czele grupy złożonej z trzech osób, lecz tylko on był wpisany do rejestru jako żołnierz. W praktyce więc rekrutowano trzykrotnie więcej vojnuków, niż wynikałoby to z zapisów. Vojnucy byli zorganizowani we własne chorągwie, w początkowym okresie mieli własną organizację, a nawet własnego sandżak-bega. Pełnili oni konną służbę na wojnie głównie w charakterze oddziałów pomocniczych: zwiadowczych, aprowizacyjnych i koniuszych ${ }^{73}$.

Nieco inną funkcję pełnili martolosi przez Greków nazywani armatolami. Pełnili oni służbę przeważnie pieszą na miejscu lub w bliskiej okolicy, często o charakterze porządkowym. Do pełnienia tej funkcji wyznaczani byli mężczyźni z konkretnych wsi. Również Vlasi z konkretnych wsi pełnili służbę zwaną derbend. Polegała ona na ochronie ważniejszych dróg, przepraw, karawan kupieckich, a czasem nawet transporcie cennych produktów. Odrębną grupę stanowili kiradżi - których służba polegała na hodowli koni oraz sokolnicy, których wsie funkcjonowały na prawie wołoskim, choć ludność przeważnie nie była wołoska ${ }^{74}$.

Zaangażowanie wojskowe dawało Vlachom duże ulgi i możliwości awansu. Wszyscy pełniący służbę w jakiejkolwiek formie byli początkowo całkowicie, a później w dużej mierze zwolnieni od podatków. Według defteru z 1477 roku z terenu Hercegowiny Vlasi powołani do jakiejkolwiek służby wojskowej czy strażniczej nie

72 Poimečni popis sandžaka vilajeta Hercegovina 1477, red. Ahmed S. Aličić, Sarajevo 1985, s. 26.

73 А. Матковски, Номадското сточарство во Македонија од XIV до XIX век, Скопје 1996, s. $18-19$.

${ }^{74}$ Ibidem, s. $20-21$. 
płacili absolutnie nic, natomiast w prawie wołoskim z czasów sułtana Sulejmana każdy dom został obciążony filurią:

\begin{abstract}
Braničewscy i widyńscy Vlasi nie płacą ani haraczu, ani dziesięciny, ani ispendże, zostali pomiłowani i nie płacą żadnych podatków, nawet podatku weselnego nie płacą. Globe i kazne płacą. Od globy $i$ kazny, co ich dają sandżakbejowi, knezowie zabierają dziesięcinę. Wspomniani Vlasi dają jedną kopię na 5 domów. Oni pełnią straż w wyznaczonych miejscach. Jak się pojawi nieprzyjaciel wszyscy Vlasi wojują konno, nie wyłączając muzułmanów. Od każdego dymu dają sandżakbejowi rocznie 83 akcze.

Smederewscy Vlasi nie płacą ani haraczu, ani dziesięciny, ani ispendże, ani podatku od owiec, ani podatku weselnego, ani żadnych innych podatków, tylko na dzień narodzin Jezusa, który oni w swojej wierze nazywają Boże Narodzenie (Božić) dają od każdego domu jedną filurię czterdzieści pięć akczy i piętnaście akczy jako wartość jednego barana i jedną filurię na 50 domów tworzących katun, za jeden namiot dają dwa barany lub ich równowartość, dwa sznury konopne i trzy naczynia oleju, co razem daje po trzy akcze. To dają na Boże Narodzenie. Wiosną, na dzień, który się zowie Hizr Iljasz [tzw. Đurđevdan, czyli dzień św. Jerzego - 23 kwietnia] od jednej filurii czyli od jednego domu dają równowartość jednej owcy z jagnięciem czyli 20 akczy, razem płacą 83 akcze. Jeden na 5 domów (filurii) pełni wojenną służbę. Oni strzegą określonych miejsc. Gdy wybuchnie czetnicka wojna z każdego domu jeden idzie na wojnę... ${ }^{75}$
\end{abstract}

Wyróżniający się żołnierze, w szczególności primićurzy, knezowie, wojewodowie bywali nagradzani timarami, a nawet ziametami i przechodzili do warstwy sipahih. Mimo wszystko też jednak na ogół byli zainteresowani z zachowaniu tradycyjnej struktury korporacji pasterskiej, w której mieli dominującą pozycję ${ }^{76}$. Ponadto warunkiem wszelkiej kariery w Imperium Osmańskim było wyznanie islamskie, natomiast w strukturach wołoskich takiego przymusu nie było. Dlatego też wiodące rody wołoskie trzymały się swych funkcji, a sułtan na ogół bez większych przeszkód akceptował na stanowisku primićura, kneza czy wojewody kolejnego członka rodu wydając mu firman na sprawowanie swej funkcji, z której mógł go odwołać jedynie w wypadku poważnego przewinienia ${ }^{77}$.

Pisząc o prawie wołoskim nie sposób nie wspomnieć o najbardziej znanym statucie wołoskim cesarza Ferdynanda II z 1630 roku. Należy jednak zwrócić uwagę na to, że o ile statut ten bardzo dokładnie regulował kwestie samorządowe i wojskowe, praktycznie nie dotyczył spraw gospodarczych ani pasterskich. Był to bowiem podstawowy dokument prawny dotyczący organizacji wsi Pogranicza Wojskowego i adapta-

75 B. Đurđev, Nešto o vlaškim starešinama pod turskom upravom, „Glasnik zemaljskog muzea” 1940, s. 58-60.

76 Vlasi ili Morlaci, prišli su Turcima velikim oduševljenjem. Oni su s turskim gospodstvom najviše dobili. Od najnižega socijalnog položaja oni su u turskom vladanju stekli lično pravo slobode kretanja i paše, mogućnost postizavanja viših socijalnih položaja, a što je glavno, Vlasi su u vrlo veliku broju unišli u tursku organizaciju neredovite vojske, zvane „martolozi”, u koju su donekle stupali i negdašnji koloni i kmetovi. Kao martolozi oni su imali velike koristi, jedno materijalne od plijena, a drugo socijalne, jer su u toj ratničkoj turskoj organizaciji stvarali sebi položaj u društvu, koji inače ne bi bili stekli pastirskim načinom svoga života; S. Pavičić, Starosjedilaštvo današnjeg hrvatskog naselja u Srednjoj i Sjevernoj Dalmaciji. Prilog k proučavanju porijekla Bunjevaca, [w:] Vlasi u starjoj hrvatskoj historiografiji, s. 79.

77 B. Đurđev, Nešto o vlaškim starešinama, s. 59. 
cji do tego celu prawa wołoskiego ${ }^{78}$. Za pomocą tego aktu prawnego wołoskie struktury społeczne i związany z nimi samorząd zostały transplantowane do wsi rolniczych (również przejętych później przez Osmanów), co w dalszej perspektywie przyniosło rozwój bujulurdiji - wiejskich instytucji samorządowych na ziemiach serbskich.

Obserwując funkcjonowanie prawa wołoskiego możemy zauważyć podobny jego rozwój na całym terenie, na którym było ono stosowane, niezależnie od tego, czy były to państwa o tradycji zachodnioeuropejskiej, bizantyńsko-prawosławnej, czy Imperium Osmańskie. Także ewolucja tego prawa przebiegała podobnie i w podobnym czasie. Możemy zaobserwować następujące etapy tej ewolucji:

1. do XIV wieku kształtowanie się systemu społecznego i samorządowego wspólnot wołoskich

2. wiek XIV-XVI - procesy osadnicze i intensywna kolonizacja na prawie wołoskim

3. wiek XVI-XVIII - podejmowanie przez część Vlachów zajęć rolniczych $\mathrm{i}$ utrata przez nich prawa wołoskiego

4. wiek XV-XVIII - wykorzystanie zasad prawa wołoskiego do budowy statusu prawnego Pograniczy Wojskowych

5. wiek XIV-XVIII - przechodzenie knezów, wojewodów i primićurów do stanu szlacheckiego lub warstwy timariotów.

\section{KIERUNKI AKTYWNOŚCI GOSPODARCZEJ VLACHÓW}

Wśród Vlachów bałkańskich podstawową u zarania czynnością gospodarczą było pasterstwo. Najstarsza informacja (jeśli przyjąć ją za prawdziwą, bo sprawa jest dyskusyjna) pochodząca z VII wieku mówi o Rhinovlachach - pasterzach na Górze Athos. Gospodarka pasterska Vlachów, w zależności od czasu i miejsca, miała charakter w pełni wędrowny bądź transhumacyjny. Podstawę organizacyjną stanowiła wspólnota pasterska - katun - odpowiednik karpackiego szałasu. Katun ewoluował ze wspólnoty rodowo-plemiennej w kierunku wspólnoty terytorialnej (wsi) i wspólnoty zawodowej, związanej głównie z pasterstwem, ale nie tylko.

Do najstarszych opisanych sposobów gospodarki pasterskiej bałkańskich Vlachów należy system sezonowej zmiany pastwisk letnich na zimowe i odwrotnie. System ten opisał po raz pierwszy w XI wieku Katakalon Kekaumenos. Wspomniał on mianowicie o tym, że pasterze z gór Pindos przenosili się na zimę do Tesalii z całym swym dobytkiem, owcami i rodzinami. I w jednym i w drugim miejscu mieli oni swoje stałe siedziby i stałe pastwiska ${ }^{79}$. Może to wskazywać, że Vlasi na tym terenie bardzo szybko zaczęli zamieszkiwać w stałych domach. Być może dlatego nazywano ich

\footnotetext{
78 Z. Blažević, Statuta Valahorum. Prilozi za kritičko izdanje, Zagreb 1999, passim.

79 Kekaumenos, [w:] Testimonia Najdawniejszych Dziejów Słowian, s. 90-91.
} 
Kucovlachami, czyli, jak sądzę, Vlachami mieszkającymi w małych domkach - ku$\operatorname{ciach}^{80}$, w odróżnieniu od Vlachów pełnych nomadów zamieszkujących bardzo długo w namiotach lub szałasach.

Taki sam sposób gospodarowania na tym terenie opisali dwaj etnologowie angielscy Alan John Bayard Wace i Maurice Scott Thompson prowadzący badania terenowe w latach 1910-1911. Wzięli oni udział w przeprowadzce z zimowego miejsca zamieszkania na letnie, a konkretnie z Tirnavos w Tesalii do odległej o $160 \mathrm{~km}$ Samariny. Vlaška populacja z tej wsi liczyła wówczas około 100 rodzin i w całości przenosiła się na miejsce letniego pobytu, mimo że już wówczas tylko jej część zajmowała się pasterstwem. Nie przeszkodził też temu zaistniały na przełomie XIX i XX wieku fakt, że Tesalia znajdowała się wówczas na obszarze państwa greckiego, a Samarina na terenie Turcji. Wielowiekowa tradycja okazała się silniejsza i obydwa państwa musiały ją zaakceptować. Część Vlachów jednak po tym, jak w 1881 roku Tesalia została przyłączona do Grecji, aby nie przechodzić przez granicę założyła na południowych stokach Pindos Nową Samarinę, była to jednak mniejszośćc ${ }^{81}$.

Przeprowadzka zaczynała się w końcu maja i trwała około tygodnia. Cały dobytek ładowano na muły, rzadziej konie. Grupy wędrujących w wysokie góry Vlachów spotykały się zwyczajowo 30-31 maja na targu w Gravenie. Na miejsce docierały po tygodniu wędrówki ${ }^{82}$.

Samarina liczyła wówczas około 800 gospodarstw i nie wszyscy przenosili się na zimę do Tirnavos. Miejscami zimowania mieszkańców Samariny były również Janina, Delvinu, Berat, Graveni, Hrupišti, Satištu, Kozani, Elasoni, Kalabaki, Trikali, Kardici i Larisi, a także wsie w pobliżu tych miejscowości: Vlahojani k. Elasone, Tatar i Makrihore k. Larisy. Obok Tirnavos, najwięcej mieszkańców Samariny zimowało w Trikali (300 rodzin), Kardici (200 rodzin) i Larisie (150 rodzin $)^{83}$.

Podobny styl życia prowadzili do XIX wieku mieszkańcy Metsova i Malakasi ${ }^{84}$.

Co ciekawe, identycznie gospodarują tam Vlasi do dziś. Mieszkańcy Samariny i okolicznych wiosek (Perivoli, Avdella, Smixi i Helimodi) żyją praktycznie na dwa domy letni w wysokich górach i zimowy w Tesalii. W wysokich partiach gór Pindos i Gramos przez ponad pół roku całe wioski stoją puste. Mieszkańcy na okres zimowy przenoszą się do różnych miejscowości nie tylko na terenie Tesalii, ale też innych części Grecji. W okresie osmańskim często były to także tereny dzisiejszej Północnej Macedonii. Zwyczaje te kultywują też niektórzy zajmujący się pasterstwem mieszkańcy innych miejscowości, np. Metsova ${ }^{85}$.

${ }^{80}$ Zob. serb. kuča - dom. Słowo to znają też górale śląscy wołoskiego pochodzenia właśnie w znaczeniu, mały domek, chatka. Na temat znaczenia określenia Kucowołosi/Kucovlasi są bardzo liczne teorie. Jedna z nich wywodzi je od tureckiego słowa küçük - „mały”, co oznaczałoby „Mali Wołosi”.

81 A. J. B. Wace, M. S. Thompson, Balkanski nomadi. Prikaz života i običaja Vlaha sa severnih Pinda, Pančevo 2009, s. 24.

82 Ibidem, s. 21-38.

83 Ibidem, s. 44.

84 A. Koukoudis, The Vlachs: metropolis and diaspora, Thessaloniki 2003, s. 82.

85 Informacje pozyskane w trakcie badań terenowych w Metsowie w $2017 \mathrm{r}$. 
Mimo swej popularności ten system nie był najbardziej typowy. Katuny, które znalazły dogodne miejsce do życia przez cały rok, tworzyły tam z czasem stałe całoroczne wsie. Wypas na pastwiskach letnich i zimowych prowadziła tylko wyspecjalizowana w tym część społeczności, wyłoniona spośród mężczyzn. Organizacja wypasu była przywilejem rodowym, prawo do organizowania własnych katunów/salaszy nowego typu mieli tylko przedstawiciele vlaskiej elity. Katun skupiał kilka, kilkanaście, czasem kilkadziesiąt rodzin wspólnie prowadzących wypas. Ten typ gospodarki pasterskiej dominował w centralnej części Bałkanów oraz w Karpatach przynajmniej od czasów, z których posiadamy już pewien materiał źródłowy ${ }^{86}$. Owce na okres zimowy spędzano w dogodne miejsca, często wspólne dla wielu grup pasterskich, gdzie przetrzymywano je w zadaszonych owczarniach i dokarmiano ususzonym wcześniej sianem, gałęziami cetynii (specjalnej odmiany sosny) $)^{87}$ itd. Przykładem takiego miejsca jest do dnia dzisiejszego Owcze Pole w Północnej Macedonii ${ }^{88}$. Takie miejsca wspólnych zimowisk obserwujemy też w Bośni i Hercegowinie oraz na Wołoszczyźnie. Na niektórych terenach Hercegowiny (np. okolice Dabaru) wypas owiec i kóz na pastwiskach prowadzono przez okrągły rok, jedynie konie wypasano na pastwisku tylko latem, a zimą trzymano w stajni. Na Wołoszczyźnie odwrotnie - konie przepędzano zimą na łęgi naddunajskie, na których dokopywały się trawy, a owce trzymano w zadaszonych owczarniach. W Mołdawii, gdzie hodowano głównie woły na rzeź, starano się je sprzedać je przed nadejściem zimy.

Na terenach nad Adriatykiem, zwłaszcza w południowej części, we wczesnym średniowieczu dominował pełny nomadyzm, całoroczna wędrówka całymi rodzinami zamieszkującymi w namiotach. Taki tryb życia prowadzili Arvanito-vlasi, zwłaszcza Farszerioci, można również ten typ pasterstwa dostrzec na terenie Hercegowiny. Nomadyzm począł stopniowo zanikać, w XVI wieku nie widać już w defterach osmańskich swobodnych katunów w Bośni i Hercegowinie, natomiast na terenie Albanii nomadyzm przetrwał dłużej, miejscami nawet do XIX wieku. O ile w Bośni i Hercegowinie nomadzi zamieszkiwali prawdopodobnie głównie w namiotach, o tyle albańscy Farszerioci zamieszkiwali w szałasach z gałęzi i siana.

Ze wszystkimi formami pasterstwa wiąże się kwestia własności pastwisk. Pełen nomadyzm można było swobodnie uprawiać w czasie, gdy tereny górskie nie miały konkretnych właścicieli, jednak od XI-XII wieku zaczęły być one coraz lepiej kontrolowane przez państwo oraz nadawane i sprzedawane konkretnym właścicielom. Tereny pasterskie nadawane były np. monasterom wraz z wypasającymi na nich Vlachami, którzy automatycznie pozbawiani byli prawa przenoszenia się poza teren należący do monasteru, co powinno zmuszać ich do osiedlania się w jednym miejscu i porzucania pełnego nomadyzmu. W praktyce jednak mnisi przeważnie nie byli

${ }^{86}$ M. Luković, Transhumantni migrace pastevců v centrálnich a západnich oblastech Balkánu [w:] Tradični agrárni kultura v kontextu společenského vývojestřední Evropy a Balkánu, Brno 2012, s. 145196, 250-251.

87 Opis czynności pasterskich: А. Матковски, Номадското сточарство, s. 155-178.

${ }^{88}$ Badania terenowe przeprowadzone w $2017 \mathrm{r}$. 
w stanie wyegzekwować swoich praw i ostatecznie katuny wołoskie zajmowały tereny należące do monasterów ${ }^{89}$. Prowadzeniu tradycyjnej gospodarki pasterskiej sprzyjała własność państwowa i duża własność ziemska. Na terenach najdłużej znajdujących się pod władzą Bizancjum (Góry Pindos, Epir, Tesalia) zachowała się wspólnota ziemi i pastwisk. Na terenach w pobliżu dużych miast nadadriatyckich rozszerzających swe granice kosztem pastwisk następował niejednokrotnie ich wykup przez co bogatszych wojewodów vlaskich. W ten sposób prawdopodobnie powstały wielkie majątki Balšiciów i Muzakich. Z kolei w wielkich majątkach wielmożów bośniackich Pavloviciów i Kosačów aż do czasów osmańskich koczowały liczne katuny Vlachów. Dotyczy to również chorwackich Šubiciów i Kačiciów.

Na terenie Węgier (w Siedmiogrodzie i na Słowacji) Vlasi funkcjonowali początkowo głównie na ziemiach królewskich ciesząc się swoistą autonomią. Madziaryzacja wojewodów wołoskich z terenów Siedmiogrodu przyspieszyła proces przechodzenia ich do grupy szlachty i częściowego rozpadu tradycyjnych struktur. Przechodzenie dotychczasowych pasterzy do gospodarki rolniczej powodowało ich degradację do stanu chłopów ${ }^{90}$.

Część Wołochów zajmowała się też gospodarką leśną, wypalaniem potażu, smolarstwem. Niektórzy wojewodowie pełnili też zarazem funkcje leśników.

Najczęściej spotykanymi zwierzętami hodowlanymi Vlachów były owce, znakomicie nadające się do wypasu w wysokich górach. Obok owiec hodowano też kozy, nie były one jednak traktowane jak pełnowartościowy materiał hodowlany, dlatego zapewne dość rzadko spotykamy je w spisach podatkowych, prawdopodobnie odnotowywano tylko większe stada. W niższych partiach gór wypasano krowy, woły, muły i konie. Wraz z wypasem owiec, kóz i krów rozwinęło się przetwórstwo mleka. Już w XIV wieku anonimowy autor opisu południowo-wschodniej Europy pisał, że Wołosi produkują najlepsze mleko i sery. Wynalazkiem Vlachów była produkcja sera w owczym żołądku, a później na podpuszczce otrzymywanej z owczego, a jeszcze lepiej jagnięcego żołądka. Przyspiesza to znacznie proces i pozwala produkować ser ze słodkiego mleka, niemal natychmiast po wydojeniu. Ten sposób otrzymywania sera stanowi jeden z wyznaczników tradycji kultury wołoskiej.

$\mathrm{Z}$ pasterstwem wiązało się również przetwórstwo skór i wełny ${ }^{91}$. Wołosi byli nie tylko samowystarczalni, ale również produkowali liczne towary na sprzedaż. Wełna dziś już nieistniejącej rasy owiec ,walaszek” była wprawdzie szorstka, ale miała tę ogromną zaletę, że była nieprzemakalna. W czasach, gdy nie było sztucznych tworzyw, sukno otrzymywane z tej wełny było ogromnie poszukiwane i drogie. W związku z tymi potrzebami rozwinęło się wyspecjalizowane tkactwo, farbiarstwo, krawiectwo.

${ }^{89}$ М. Благојевић, Планине и пашњащчи у средњовековној Србији (XIII и XIV век), „Историйски гласник" 1966, t. 2-3, s. 38-39.

${ }^{90}$ V. Chaloupecky, Valaši na Slovensku, Praha 1947, s. 89.

${ }^{91}$ Ibidem, s. 95. 
Aktywność handlowa Vlachów była równie intensywna jak działalność hodowlana i produkcyjna. Wiele wsi wołoskich, jak np. Gravena czy Samarina było też ważnymi ośrodkami handlu, towary vlaskie sprzedawano też w miastach, takich jak Janina, Veria czy Tessalonika. Ważnym punktem handlu sprzedającym towary wołoskie, głównie żywe zwierzęta, był Dubrownik ${ }^{92}$. Najważniejszym jednak ośrodkiem handlu Vlachów było Moskopole na terenie dzisiejszej Albanii. W 1 połowie XVIII wieku miasto należało do najbogatszych w Imperium Osmańskim, liczyło ok. 80 tys. mieszkańców, posiadało własną szkołę średnią i akademię, wybudowano w nim też ponad 20 cerkwi ozdobionych freskami wysokiej klasy,. Miasto to straciło swe znaczenie po dwukrotnym spaleniu w 1769 i $1789 \mathrm{r}^{93}$.

Moskopole i inne miasta, które stały się ważnymi ośrodkami handlu i kultury sprzyjały wykształceniu się warstwy bogatego mieszczaństwa wołoskiego, przeważnie zhellenizowanego, określanego na Bałkanach mianem Cincarów ${ }^{94}$.

Zaangażowanie Vlachów w handlu nie tylko wynikało z konieczności sprzedaży własnych towarów, ale również ze specjalnych zadań, jakie wykonywać musieli na polecenie rządzących. Była to organizacja i ochrona karawan kupieckich, organizowanie przepraw przez szczególnie trudne odcinki górskie i przez rzeki.

I tak na terenie Dalmacji Vlasi zajmowali się tradycyjnie transportem soli do miast nadadriatyckich. Dokument z roku 1352 wskazuje, że przewozili sól z Zadaru do Wenecji. Podobnie Vlasi z Serbii i Bośni wozili sól do Dubrownika ${ }^{95}$. Na Węgrzech i w Bośni zatrudniani też byli w górnictwie, głównie solnym ale nie tylko, zajmowali się bowiem również wydobyciem srebra ${ }^{96}$.

Znakomita orientacja w trudnym terenie i sprawność vlaskich górali sprawiała, że stali się oni również pożądanym materiałem wojskowym, o czym już wyżej wspomniano. W jakimkolwiek państwie by się nie znaleźli, egzekwowano od nich obowiązek wojskowy.

Podsumowując należy stwierdzić, że Wołosi to nie tylko jedna z wielu grup etnicznych w mozaice tworzącej komponent europejski, to także istotny element cywilizacyjny. To prawo wołoskie ukształtowało w całej południowo-wschodniej Europie system samorządowy na wsi. Prawo wołoskie wykorzystywano jako podstawę wszelkiego rodzaju osadnictwa wojskowego, tak istotnego na pograniczu między Imperium Osmańskim a państwami chrześcijańskimi. Pozornie prosty, czasem uważany za prymitywny i pogardzany sposób życia i gospodarowania był efektem wielowiekowej

92 Ciekawy materiał w tym względzie stanowi księga transakcji handlowych z wojewodami wołoskimi z terenów dzisiejszej Czarnogóry (najwięcej z wojewodą z Rudine) z lat 1594-1667; Državni Arhiv u Dubrovniku, F. 31, t. A2 nr 41. Głównym przedmiotem transakcji były zwierzęta, czasem też sery i masło.

93 N. Trifon, Cincarii narod koji nestaje, Beograd 2010, s. 186-202; V. Papahagi, Aromâni moscopoleni şi comerţul veneţian în secolele al XVII-lea şi al XVIII-lea, Bucureşi 1935, passim.

94 Zob. też Д. Ј. Поповић, О цииицарима, Београд 2008, passim.

95 V. Klaić, Vlasi u Hrvatskoj tečajem 14. i 15. stoljeća, [w:] I. Mužić, Vlasi u starjoj hrvatskoj historiografiji, s. 11.

96 N. Filipović, Islamizacija u Bosni i Hercegovini, Sarajevo 2008, s. 335. 
tradycji przystosowania się do ekstremalnych nieraz warunków panujących w górach, był to jedyny skuteczny i efektywny sposób gospodarowania na tym terenie.

\section{BIBLIOGRAFIA}

\section{Źródla:}

Anna Comnena, The Alexiad, thum. Elizabeth A. S. Dawes, Cambridge, Ontario 2000.

Anna Komnena, Aleksjada, tłum. Oktawiusz Jurewicz, t. 1-2, Wrocław-Warszawa-Kraków 1967-1971.

Anonymi Bellae Regis notarii Historia Hungarica de septem primis ducibus Hungariae, [w:]

J. Schwandtner, Scriptores Rerum Hungaricarum, t. 1, Vindobonae 1746.

Anonymi Descriptio Europae Orientalis, red. O. Górka, Cracoviae 1916.

Anonymus Bele regis notarius, Gesta Hungarorum, wyd. G. Popa-Lisseanu, Bucureşti 1934.

Codex diplomaticus Regni Croatiae, Dalmatiae et Slavoniae, red. M. Kostrenčić, t. 1, Zagrabiae 1967.

Constantinus Porphyrogenitus, De thematibus et administrando imperio, Bonn 1840.

Documenta Romaniae Historica, red. Petre P. Panaitescu, Damaschin Mioc, B (Tara Românească), t. 1 (1247-1500), Bucureşti 1966.

Državni Arhiv u Dubrovniku, F. 31, 41/A1-A2.

Dva prva popisa Zvorničkog sandžaka iz 1519 i 1533, „Мешовита грађа” („Miscellanea”) 1986, t. 26.

Geoffroy de Villehardouin, Zdobycie Konstantynopola, tłum. i kom. Zdzisław Pentek, Poznań 2003.

Georgii Pachymmeris, de Michaele et Andronico Paleologis, ex recensione Immanuelis Bekeri, Bonnae 1835.

Georgius Cedrenus, Joannus Skylitzes opere, t. 2, Bonnae 1839.

Gilferding Aleksandar F., Putovanje po Hercegovini, Bosni i Staroj Srbiji, wyd. 2, Beograd 1996 [Гиљфердинг Александрар Ф., Путовање по Хериеговини, Босни и Старој Србији, изд. 2, Београд 1996].

Inwentarze i rozliczenia folwarczne wsi Kobylnicy Ruskiej i Kobylnicy Wołoskiej z lat 1711-1723, red. Bogumiła Kowal, Stanisław Baran, Przemyśl 2014.

Izvori za B'lgarskata Istorija, t. 22: Grcki Izvori za B'lgarskata Istorija, t. 10, M. Vojnov, V. T'pkovaZaimova, L. Jončev, Sofija 1980 [Извори за Българската История, t. 22: Гръики Извори за Българската История, t. 10, М. Войнов, В. Тьпкова-Заимова, Л. Йончев, София 1980].

Izvori za B'lgarskata Istorija, t. 25: Grcki Izvori za B'lgarskata Istorija, t. 11, M. Vojnov, V. T'pkovaZaimova, L. Jončev, Sofija 1983 [Извори за Българската История, t. 25: Гръики Извори за Българската История, t. 11, М. Войнов, В. Тъпкова-Заимова, Л. Йончев, София 1983].

Jakovlević Aleksandar, Isailović Neven, Popis nahije Kosovo iz 1574 godine, „Mešovita građa” („Miscellanea”) 2013, t. 34, s. 25-70 [Јаковљевић Александар, Исаиловић Невен, Попис нахије Косово из 1574 године, „Мешовита грађа” („Miscellanea”) 2013, t. 34, s. 25-70].

Jovan Kantakuzin, [w:] Vizantijski izvori za istoriju naroda Jugoslavije, t. 6, Beograd 1986 [Иован Кантакузин, [w:] Византийјски извори за историју народа Југославије, t. 6, Београд 1986].

Katić Tatjana, Opširni popis prizrenskog sanđaka iz 1571. godine, Beograd 2010 [Катић Татјана, Опширни попис призренског саниака из 1571. године, Београд 2010].

Markov Evgenij, Putovanje po Srbiji i Crnoj Gori, Podgorica 2005 [Марков Е., Путовање по Србији и Црној Гори, Подгорица 2005].

Mihályi János, Máramarosi diplómak a XIV. és XV századból, Máramaros-Sziget 1900, s. 245-246.

Miklosich Franz, Monumenta Serbica spectantia historiam Serbiae, Bosnae, Ragusii, Viennae 1858.

Nicetae Choniatae, Historia, ex recensione Immanuelis Bekeri, Bonnae 1835.

Opširni katastarski popis za oblast Hercegovu iz 1585 godine, tłum. Ahmed S. Aličić, t. 2, Sarajevo 2014.

Opširni popis Bosanskog sandžaka 1604 godine, red. A. Kupusović, t. 1-3, Sarajevo 2000. 
Opširni popis kliškog sandžaka iz 1550 godine, red. Fehim Dž. Spaho, Ahmed S. Aličić, Sarajevo 2007.

Panaitescu Petru P., Documentele Ţării Româneşti, t. 1 (Documente interne; 1369-1490), Bucureşti 1938.

Poimečni popis sandžaka vilajeta Hercegovina 1477, red. Ahmed S. Aličić, Sarajevo 1985.

Robert de Clari, Zdobycie Konstantynopola, tłum. i kom. Zdzisław Pentek, Poznań 1997.

Scriptores Rerum Hungaricarum, t. 1, wyd. E. Szentpétery, Budapestini 1937.

Solovjev Aleksandar, Odbrani spomenici srpskog prava (od XII do kraja XV veka), Beograd 1926.

Stojaković Momčilo, Braničevski tefter. Poimenični popis Pokrajne Braničevo iz 1467. godine, Beograd 1987.

Sumarni popis sandžaka Bosna iz 1468/69 godine, red. Ahmed S. Aličić, Mostar 2008.

Testimonia Najdawniejszych Dziejów Stowian. Seria Grecka, z. 6. Pisarze wieku XI, thum. i kom. A. Kotłowska, współpr. A. Brzóstkowska, Warszawa 2013.

Vizantijski izvori za istoriju naroda Jugoslavije, t. 3, Beograd 1966 [Византийјски извори за историју народа Југославије, t. 3, Београд 1966].

\section{Opracowania:}

Arion Dinu C., Le „Nоцоб үєорүıкоб” et la régime de la terre dans l'ancien droit roumain jusqu'a la reforme de Constantin Mavrocordat (hospodar de Moldavie et de Valachie (1733-1769), Paris 1929.

Aromâni, meglenoromâni, istroromâni - aspecte identitare şi culturale, red. Adina Berciu-Drăghicescu, Bucureşti 2012.

Blagojević Miloš, Planine i pašnjaci v srednjovekovnoj Srbiji (XIII-XIV vek), „Istorijski glasnik“ 1966, t. 2-3, s. 3-95 [Благојевић Милош, Планине и пашњащи у средњовековној Србији (XIII и XIV век), „Историйски гласник” 1966, t. 2-3, s. 3-95].

Blažević Zrinka, Statuta Valahorum. Prilozi za kritičko izdanje, Zagreb 1999.

Bujduveanu Tănase, Aromânii şi Muntele Athos, București-Constanţa 2002.

Caciur Dana Silvia, Considerations regarding the Morlachs migrations from Dalmatia to Istria and the Venetian settlement policy during the 16th century, „Balcanica Posnaniensia. Acta et studia” 2015, t. 22 , nr 1, s. 57-70.

Chaloupecky Václav, Valaši na Slovensku, Praha 1947.

Costachel Valeria, Panaitescu Petre, Cazacu A., Viaţa feudală în Ţara Românească şi Moldova (sec. XIVXVII), Bucureşti 1957.

Czamańska Ilona, Vlachs and Slavs in the Middle Ages and Modern Era, „Res historica” 2016, t. 41, s. 11-24.

Czamańska Ilona, Wotosi/Vlasi z terenów Hercegowiny w świetle defterów osmańskich z XV i XVI wieku, „Balcanica Posnaniensia. Acta et studia” 2018, t. 25, s. 219-249.

Dobrowolski Kazimierz, Migracje wołoskie na ziemiach polskich, [w:] Pamiętnik V Powszechnego Zjazdu Historyków Polskich w Warszawie 28 listopada do 4 grudnia 1930 r., Lwów 1930, s. 135-152.

Dudek Jarosław, Status Wołochów w jedenastowiecznym Bizancjum (wg „Rad” Kekaumena), „Balcanica Posnaniensia. Acta et studia" 2018, t. 25, s. 197-218.

Đurđev Branislav, Nešto o vlaškim starešinama pod turskom upravom, „Glasnik zemaljskog muzea” 1940, s. 49-67.

Figlus Tomasz, Villae iuris valachici. Z problematyki rozwoju osadnictwa wołoskiego w Polsce na przyktadzie ziemi sanockiej, ,, Studia z geografii politycznej i historycznej” 2016, t. 5, s. 11-37.

Filipović Nedim, Islamizacija u Bosni i Hercegovini, Sarajevo 2008.

Ghimpu Vlad D., Izvoare medievale româneşti din Rusia şi Finlanda, Chişineu 2012.

Hrabak Bogumil, Stari Vlah od XV do početka XIX veka, „Novopazarski zbornik” 1999, t. 23, s. 55-80 [Храбак Б., Стари Влах од XV до почетка ХIХ века, „Новопазарски зборник” 1999, t. 23, s. 55-80].

Jawor Grzegorz, Osady prawa wołoskiego i ich mieszkańcy na Rusi Czerwonej w późnym średniowieczu, Lublin 2004.

Jawor Grzegorz, Strungi i zbory. Instytucje organizacji społecznej wsi na prawie wołoskim w średniowiecznej Polsce, „Kwartalnik Historii Kultury Materialnej” 1997, t. 45, nr 2, s. 179-186. 
Jawor Grzegorz, Wspótistnienie grup etnicznych na Rusi Czerwonej w XV-XVI wieku na przykładzie stosunku do społeczności wołoskich, "Annales Universitatis Mariae Curie-Sklodowska” 1997/1998, t. 52-53, s. 53-66.

Kadlec Karel, Valaši a valašské právo v zemíh slovanských a uherských, Praha 1916 (reprint 2004).

Kahl Thede, Le nomadisme chez les Aroumains, [w:] N. Trifon, Les Aroumains un peuple qui s'en va, Acratie 2012.

Katić Tatjana, Amedoski Dragana, Karavanđije nahije Petruš iz Levča 1502 godine, „Mešovita građa” 2017, t. 38, s. 7-25 [Катић Татјана, Амедоски Драгана, Караваниије нахије Петруи из Левча 1502. године, „Мешовита грађа” 2017, t. 38, s. 7-25].

Klaić Vjekoslav, Vlasi u Hrvatskoj tečajem 14. i 15. stoljeća, [w:] I. Mužić, Vlasi u starjoj hrvatskoj historiografiji, Split 2010.

Koukoudis Asterios, The Vlachs: metropolis and diaspora, Thessaloniki 2003.

Kulišić Špiro, O etnogenezi crnogoraca, Titograd, 1980.

Lopašić Radoslav, Cetinski i lički vlasi, [w:] I. Mužić, Vlasi u starjoj hrvatskoj historiografiji, Split 2010.

Lopašić Radoslav, Zakon za ličke vlahe od g. 1433, [w:] I. Mužić, Vlasi u starjoj hrvatskoj historiografiji, Split 2010.

Luković Miloš, Transhumantni migrace pastevců v centrálních a západních oblastech Balkánu [w:] Tradični agrárni kultura v kontextu společenského vývojestřední Evropy a Balkánu, Brno 2012, s. 145-196, 250-251.

Luković Miloš, Valašske pravo jako základ Valašske kolonizace - komparace z valašským právem na Balkánĕ, [w:] Valašsko historie a kultura, red. Svetava Urbanová, Lumír Dokoupil, Jakub Ivánek, Peter Kadlec, Ostrava 2014, s. 131-137.

Luković Miloš, Zakon Vlahom (,Ius Valachicum”) in the charters issued to Serbian medieval monasteries and kanuns regarding Vlachs in the early Ottoman Tax Registers (defters), „Balcanica Posnaniensia. Acta et studia" 2015, t. 22, nr 1, s. 29-46.

Matkovski Aleksandar, Nomadskoto stočarstvo vo Makedonija od XIV do XIXvek, Skopje 1996 [Матковски Александар, Номадското сточарство во Македонија од XIV до XIX век, Скопје 1996].

Meteş Ştefan, Emigrării româneşti din Transilvania în secolele XIII-XX, Bucureşti 1977, s. 46.

Mirdita Zef, Vlasi starobalkanski narod (od povijesne pojave do danas), Zagreb 2009.

Mužić Ivan, Vlasi u starijoj hrvatskoj historiografiji, Split 2010.

Oblast Brankovića. Opširni katastarski popis iz 1455 godine, red. Hamid Hadžibegić, Adem Handžić, Ešref Kovačević, Sarajevo 1972.

Onciul Dimitrie, Scrieri istorice, red. A. Sacerdoţeanu, t. 1-2, Bucureşti 1968.

Onciul Dimitrie, Teoria lui Rösler. Studii asupra stăruinţei Românilor în Dacia traiană, de A. D. Xenopol. Dare de seamă critică, Bucureşti 1885.

Papahagi Valeriu, Aromâni moscopoleni şi comerţul veneţian în secolele al XVII-lea şi al XVIII-lea, Bucureşti 1935.

Pavičić Stjepan, Starosjedilaštvo današnjeg hrvatskog naselja u Srednjoj i Sjevernoj Dalmaciji. Prilog k proučavanju porijekla Bunjevaca, [w:] I. Mužić, Vlasi u starjoj hrvatskoj historiografiji, Split 2010.

Pintescu Florin, Românii din Transilvania la sfârşitul secolului XVI şi începutul secolului XVII, Suceava 2004.

Popović Dušan Jovan, O Cincarima, Beograd 2008 [Поповић Д. Ј., О Цинцарима, Београд 2008 ].

Rösler Robert, Romänische Studien. Untersuchungen zur älteren Geschichte Romäniens, Leipzig 1871.

Šabanović Hazim, Krajište Isa-bega Ishakovića. Zbirni katastralni popis iz 1455 godine, Sarajevo 1964.

Saramandu Nicolae, „Torna, torna Fratre» et la romanité orientale au VI ${ }^{\text {e }}$ siècle, „Revue des Études Sud-Est Européennes" 2002 2002, t. 40, s. 41-60.

Šekularac Božidar, Tragovi Vlaha u Crnoj Gori, Şebeş 2012.

Semkowicz Władysław, Materiały źródłowe do dziejów osadnictwa Górnej Orawy, t. 2, Zakopane 1939. 
Şişeştean Gheorghe, Românii, care s-au stîns. Valachii din Carpaţii Nordici şi românii din Ungaria, Cluj-Napoca 2012.

Stabile Giovanni, Valacchi e Valacchie nella letteratura francese medievale, Roma 2010.

Spinei Victor, Realităţii etnice şi politice în Moldova meridională în secolele X-XIII. Români şi turanici, Iaşi 1985.

Szczotka Stanisław, Studia z dziejów prawa wołoskiego w Polsce, „Czasopismo prawno-historyczne” 1949 , t. 2, s. 355-415.

Trifon Nikola, Cincarii narod koji nestaje, Beograd 2010.

Wace Alan John Bayard, Thompson Maurice Scott, Balkanski nomadi. Prikaz života i običaja Vlaha sa severnih Pinda, Pančevo 2009.

Xenopol Alexandru Dumitru, Teoria lui Rösler. Studii asupra stăruinţei Românilor în Dacia traiană, Iaşi 1884.

Xenopol Alexandru Dumitru, Une énigme historique. Les roumains au moyen âge, Paris 1885. 